West African Papers

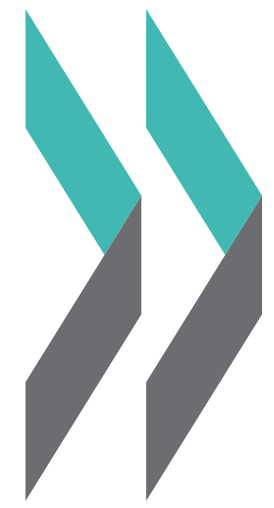

\title{
Population and Morphology of Border Cities
}

APRIL 2019 NO. 21

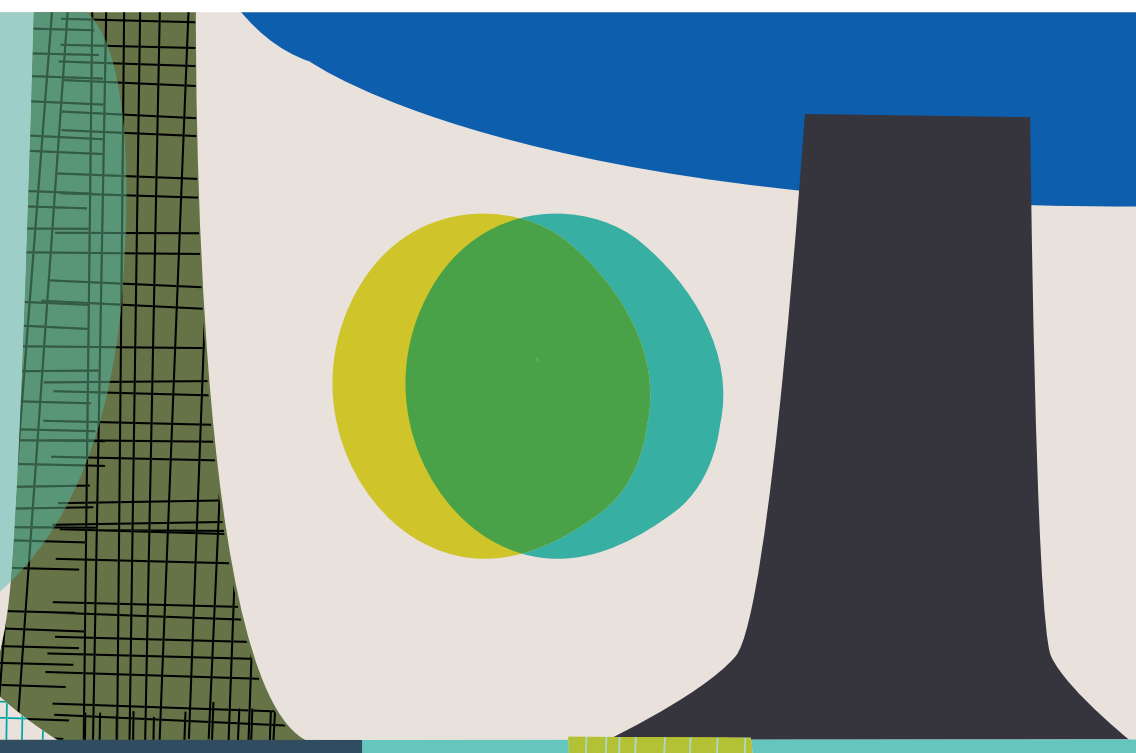





\section{POPULATION AND MORPHOLOGY OF BORDER CITIES}

"Cities" Collection

Under the direction of Marie Trémolières and Olivier J. Walther

\section{Also in this Collection:}

"Regional Integration in Border Cities", No. 20

"Businesses and Health in Border Cities", No. 22

"Accessibility and Infrastructure in Border Cities", No. 23 


\section{WEST AFRICAN PAPERS}

The West African Papers explore African socio-economic, political and security dynamics from a regional and multidisciplinary perspective. They seek to stimulate discussion and gather information to better anticipate the changes that will shape future policies. The series is designed for a wide audience of specialists, development practitioners, decision makers and the informed public. Papers are available in English and/or French, and summaries are available in both languages. Initiated by the Sahel and West Africa Club (SWAC) to highlight and promote West African issues, the work presented is prepared by its Secretariat, Members and partners, other OECD departments, related international organisations, associated experts and researchers.

Please cite this publication as:

OECD/SWAC (2019), "Population and Morphology of Border Cities",

West African Papers, No. 21, OECD Publishing, Paris.

https://doi.org/10.1787/80dfd9d8-en

ISSN 2414-2026

This paper is published under the responsibility of the Secretary-General of the OECD. The opinions expressed and the arguments employed herein do not necessarily reflect the official views of OECD member countries.

This document and any map included herein are without prejudice to the status of or sovereignty over any territory, to the delimitation of international frontiers and boundaries and to the name of any territory, city or area.

Authorised for publication by Laurent Bossard, Director, Sahel and West Africa Club Secretariat (SWAC/OECD).

You can copy, download or print OECD content for your own use, and you can include excerpts from OECD publications, databases and multimedia products in your own documents, presentations, blogs, websites and teaching materials, provided that suitable acknowledgment of OECD as source and copyright owner is given. All requests for commercial use and translation rights should be submitted to rights@oecd.org. 


\begin{abstract}
This report, part of the "Cities" collection, provides an analysis of the demographic and morphological changes in West African border cities since the mid-20th century. Using the Africapolis harmonised database makes it possible to show that since 1950 border cities have experienced higher rates of growth than other cities in the region. While the average size of cities increases with distance from a border, the opposite is true for urban density; it decreases as distance from a border increases. This suggests that border cities form urban centres that differ from other such centres due to the fact that they specialise in the commercial activities that stimulate growth and foster higher densities. The report identifies the 27 main cross-border agglomerations in the region and discusses their specific characteristics.
\end{abstract}

Key words: demography, morphology, Africapolis, urban density, cross-border agglomerations JEL classification: O18, O21, F15, F10

\title{
About the collection
}

One of the most dramatic transformations taking place in Africa, urbanisation is the result of growing demographics and societal and economic changes. Its dynamics and impacts need to be identified, mapped, measured and planned for in order to build sustainable policy options. This is the purpose of the "Cities" collection.

\section{The Sahel and West Africa Club}

The Sahel and West Africa Club (SWAC) is an independent, international platform. Its Secretariat is hosted at the Organisation for Economic Co-operation and Development (OECD). Its mission is to promote regional policies that will improve the economic and social well-being of people in the Sahel and West Africa. Its objectives are to improve the regional governance of food and nutrition security and improve the understanding of ongoing transformations in the region and their policy implications through regional, spatial and forward-looking analyses. SWAC Members and partners are Austria, Belgium, Canada, CILSS, the ECOWAS Commission, the European Commission, France, Luxembourg, the Netherlands, Norway, Switzerland, the UEMOA Commission and the United States. SWAC has memorandums of understanding with the NEPAD Agency and the University of Florida (Sahel Research Group).

More information: www.oecd.org/swac 


\section{The team and acknowledgments}

The editorial and drafting team at the SWAC/OECD Secretariat includes: Marie Trémolières, Executive Director, marie.tremolieres@oecd.org With the help of: Lia Beyeler, Freerk Boedeltje and Sylvie Letassey

Graphic design: Grand Krü Berlin/Daniel Krüger, daniel@grandkrue.de, and Martin Rümmele (maps)

This work is carried out under the memorandum of understanding with the University of Florida (Sahel Research Group).

Scientific direction, field co-ordination, mapping and drafting were provided by Dr Olivier J. Walther. Ph.D. Dr Walther is a visiting associate professor at the Center for African Studies at the University of Florida, associate professor of political science at the University of Southern Denmark and consultant for SWAC/OECD. owalther@ufl.edu

\section{External contributors:}

Hye Ryeon Jang, Ph.D. candidate at the Department of Political Science of the University of Florida. hrjang52@ufl.edu

Michiel van Eupen, expert in spatial modeling, researcher at the Alterra Research Institute (Wageningen University). michiel.vaneupen@wur.nl

Lawali Dambo, professor and researcher at the Department of Geography, Abdou Moumouni University of Niamey (Niger). lawali.dambo@gmail.com

The team thanks the following for their contribution to the writing of this report: Laurent Bossard, Philipp Heinrigs, SWAC/OECD Secretariat; Paul Nugent, Isabella Soi, Wolfgang Zeller, University of Edinburgh; Dieudonné Kam, Brahima Cissé, CILSS; Younsa Yansambou Habibatou, REACH; Edmond Sougué; Mohamadou Abdoul, Mamoudou Tapily, German Corporation for International Cooperation (GIZ);

Amadou Oumarou, Moustapha Koné, University of Niamey; Jade Siu, University of Birmingham; Laure Dumolard, World Health Organization; Moussa Ismaïla Touré, Binta Diakité, Agency for the Promotion of Investments in Mali; Sarah McKune, Leonardo A. Villalón, Greg Kiker, Alioune Sow, University of Florida; Bruce Whitehouse, Lehigh University; Armelle Choplin, University of Paris-Est; Christine Stabell Benn, University of Southern Denmark; Denis Retaillé, University of Bordeaux; Jean Rubio, Alexandra Lafont, Petia Tzvetanova, Jean Peyrony, Transfrontier Operational Mission (MOT). 


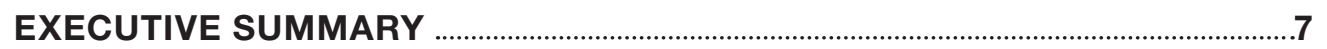

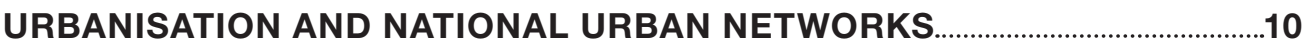

Characteristics of the urbanisation process.................................................................10

The size of cities increases with distance from borders....................................13

Border cities are growing more quickly than others...........................................21

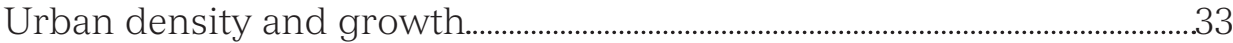

Density decreases with distance from a border............................................................36

BORDER MARKETS AND MORPHOLOGY

Why do border markets flourish? ....……………………………………………………….....4

Urban morphology.......................................................................................................................4

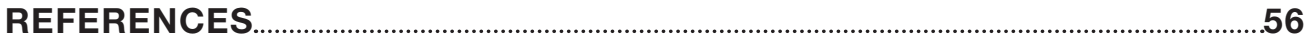

BOXES

Box 1.1 Per-country urbanisation levels and human

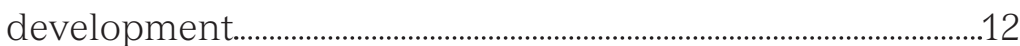

Box 2.1 Spatial restructuring in Sierra Leone-Guinea..........................49

Box 2.2 Lomé and Aflao: A special relationship.......................................54

\section{FIGURES}

Figure 1.1 Number of agglomerations with more than 10000 inhabitants, per country, 2015.

Figure 1.2 Per-country urbanisation levels and human development rankings by country, 2015.

Figure 1.3 Number and population of agglomerations, based on size in 2015.

Figure 1.4 Per-country average annual urban growth, 1950-2015......21

Figure 1.5 Demographic changes in the capital and secondary agglomerations of Niger, Mali and Senegal, 1910-2015.....26

Figure 1.6 Urban population based on distance from a border, 1950-2015.

Figure 1.7 Average annual growth of agglomerations based on distance from a border, 1950-2015. 
Figure 1.8 Urban population percentage based on distance from

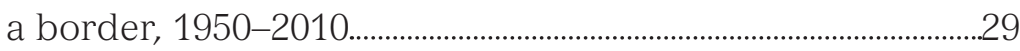

Figure 1.9 National and urban densities, 2015 ..............................................37

Figure 1.10 Density and population of million-inhabitant cities, 2015.

\section{MAPS}

Map 1.1 Agglomerations and their distance from a border, 2015......17

Map 1.2 Urban border population at $20 \mathrm{~km}$ from a border, 2015.......19

Map 1.3 Urban border population at $50 \mathrm{~km}$ from a border, 2015......23

Map $1.4 \quad$ Urban border population at $100 \mathrm{~km}$ from a border, 2015 ..

Map 1.5 Average annual growth of agglomerations at $100 \mathrm{~km}$ from a border, 2000-10.

Map 1.6 Average annual growth of border agglomerations between Ghana and Nigeria at $100 \mathrm{~km}$ from a border, 2000-10.

Map 1.7 Average annual growth of border agglomerations at $100 \mathrm{~km}$ from a border, 2010-20....................................................35

Map 1.8 Density of border agglomerations, 2015_......................................41

Map 2.1 West African border markets..................................................................4

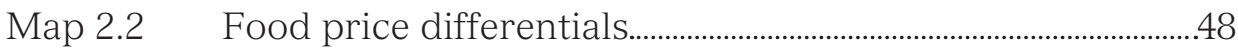

Map 2.3 Major cross-border agglomerations, by type, 2015..............50

Map 2.4 The Gaya-Malanville cross-border agglomeration

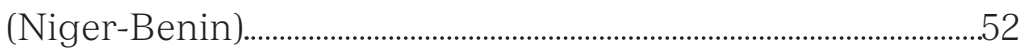

Map 2.5 The Lomé-Aflao cross-border agglomeration (Togo-Ghana). .54

\section{TABLES}

Table 1.1 Population and number of agglomerations in relation to their distance from a border, 2015.

Table 1.2 Cities and urban population per country, based on distance from a border, 2015..

Table 1.3 Population and area per country, 2015. 38

Table 1.4 Urban population based on distance from a border, 2015 .

Table 2.1 Population of major cross-border agglomerations, by type, 2015 .

This Note is based on the Africapolis database produced by SWAC. The data are based on a spatial approach and apply physical (a continuously built-up area) and demographic criterion (more than 10000 inhabitants) to define an urban agglomeration. The term city is used in this report to mean agglomeration. 


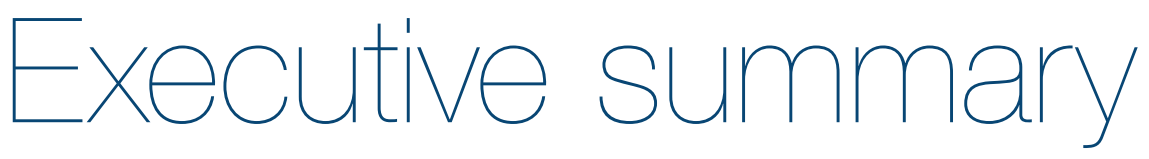

This report, composed of four West African Papers (nos. 20, 21, 22, 23) is the result of a systematic analysis of the role West African border cities play in the process of regional integration. Based on a multidimensional mapping of 18 countries, the report analyses the local dynamics that have developed in urban areas, the impact distance has on national cohesion and the impact territorial divisions have at the international level.

\section{Density, distance and division}

- At the local level, the study of demographic and morphological changes identifies the effects density has on border cities at the local level. It shows that since the mid twentieth century, the growth of border cities has almost always been greater than that of other cities in the region. This rapid growth has been especially visible within 50 kilometres of national borders, where the most dynamic markets are located. Growth has been particularly strong along Nigeria's borders and in the Gulf of Guinea between Benin and Togo. The report also confirms that border cities have very specific features. Twenty-seven of them are cross-border centres separated by land or river borders or are located on a coastline. These cross-border agglomerations emerged without a concerted development plan and remain very dependent on each other.

- At the national level, the impact of distance on border cities is studied by looking at health services and formal businesses. The map of regional health coverage shows that West African border areas are highly heterogeneous, and that the potential of harmonising the health policies of the different countries has been largely untapped. The mapping of formal businesses specialising in certain sectors of strategic importance to regional integration shows that most are located in political and/or economic capitals where decisions are made concerning customs policies as well as import/re-export strategies, and where major transportation and communications infrastructure is located. These results suggest that the lack of public investment in health services as well as roadway and education infrastructure in border regions can potentially pose major problems for national cohesion.

- At the international level, the effects of territorial divisions can be shown using an accessibility model developed to show the effects borders have on regional interactions. The results show that the population base for border cities could be 14\% larger if border crossings did not impact the flow of goods and people and 12 to 50\% larger without roadside check- 
points. Between Benin, Niger and Nigeria, an analysis of the condition of the road network shows that the combined population base of eight border cities would increase by one-third if there was no waiting at the borders. An exhaustive list of adjacent border posts in place or planned by national governments or regional organisations throughout sub-Saharan Africa further shows that trade facilitation runs up against the special interests of public servants and private-sector actors making a living from regional integration frictions. In West Africa in particular, few states are now able to benefit from the newly built border post structures in the region, most of which are not operational.

\section{Main obstacles to cross-border urban development}

The report confirms that cross-border cities lack the infrastructure needed to develop as both centres of local innovation and regional commercial hubs. This double constraint is expressed locally by urban development that is largely spontaneous and by a lack of markets, storage facilities and urban roads as well as medical, social and educational facilities. Border cities also suffer from congestion and a lack of upkeep on the road and rail infrastructure connecting them to the rest of the nation and neighbouring countries. The lack of productive, socio-educational and business investment typical of border cities considerably reduces the potential for agglomeration economies created by urban concentration. It also amplifies the negative effects of distance at the national level and imposes considerable constraints on regional trade.

From an institutional point of view, the main obstacle to the development of border cities is the low financial capacity of local and regional governments. While legal and institutional decentralisation has reached an acceptable level within the region, the tools and financial means needed to implement them are still limited. Low levels of economic independence and poor collection rates combined with a tendency to refrain from increasing taxes during election cycles are making the situation worse. Consequently, local governments lack the means to make the decentralised investments that could help them realise their urban and cross-border potential.

\section{Main recommendations}

The demographic and economic significance border cities have for regional integration justifies the need for place-based policies suited to their specific features.

- Development policies must foster the potential benefits of urban density at the local level by supporting the establishment of urban plans that maximise intra-urban interaction. The agglomeration economies created by high urban density can potentially reduce the cost of transportation and communications, foster innovation and make larger numbers of 
agricultural and manufactured products more widely available. These agglomeration economies would, however, be more easily exploitable if cities were to develop in keeping with a development plan and in concert with neighbouring border cities. The rapid population growth and urban sprawl seen today in West African border cities should encourage governments to sustainably invest in supporting these dynamics if they wish to make the most of agglomeration economies.

- Development policies should focus on reducing the distance separating border cities from other hubs in the urban network at the national level so as to minimise the inconvenience associated with their geographical marginalisation and to foster national cohesion. The development of border cities goes hand-in-hand with national policies aimed at projecting national government authority and providing services throughout the national territory.

- Development policies must continue to reduce the friction generated by the 32000 kilometres of land borders that separate the countries of West Africa at the international level. This can be achieved by facilitating the mobility of goods, people, capital and ideas over short and long distances. The transportation corridors, dry docks, joint border posts, free trade zones and pipelines currently put in place by regional organisations and national governments must be supported by development policies. 

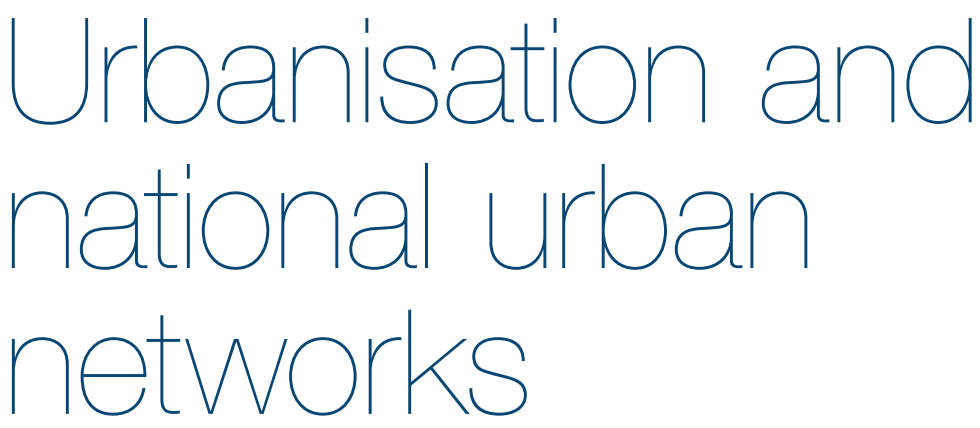

his chapter illustrates the process of rapid urbanisation resulting from
high population growth and intense internal migration. In 2015, more
than 182 million people out of 390 million were living in cities, or the
equivalent of an average urbanisation level of 47\%. Urban dwellers already make up most of the population in seven countries in the region: Cabo Verde, Cameroon, Gambia, Ghana, Nigeria, Senegal and Togo. The development of border towns is particularly rapid despite geographical disparities.

\section{Characteristics of the urbanisation process}

From a geographical perspective, the regional distribution of cities is markedly uneven. Close to half of the region's 2469 agglomerations with more than 10000 inhabitants are located in Nigeria, while less than $10 \%$ of them are located in Côte d'Ivoire and Ghana (Figure 1.1). Small countries such as Cabo Verde, Gambia and Guinea-Bissau, sparsely populated ones like Mauritania and those dominated by one big city, as is the case in Guinea, Liberia and Sierra Leone, have fewer than 50 cities. The degree of centralisation of the national urban network and the relative weight of national cities within the urban population are additional factors likely to influence the size and growth of cities. Three scenarios can be identified depending on whether the urban network is dominated by a capital city, by two metropolitan centres or by a number of large cities.

Nine West African countries have a macrocephalic urban system, in which all of the country's essential commercial and political functions and a large percentage of its urban population are concentrated in one urban area. This situation represents a deviation from the theoretical urban population distribution, known as Zipf's law, according to which the size of an agglomeration will be double that of the city with the next smallest population. If the largest city in the country has one million inhabitants, the second will, in theory, have a population of half a million or a ratio of 2:1. In Liberia, Guinea, Togo and Mali, the ratio is greater than 10, a high indicator of urban primacy for Monrovia, Conakry, Lomé and Bamako in relation to the secondary cities in 


\section{Figure 1.1}

Number of agglomerations with more than 10000 inhabitants, per country, 2015

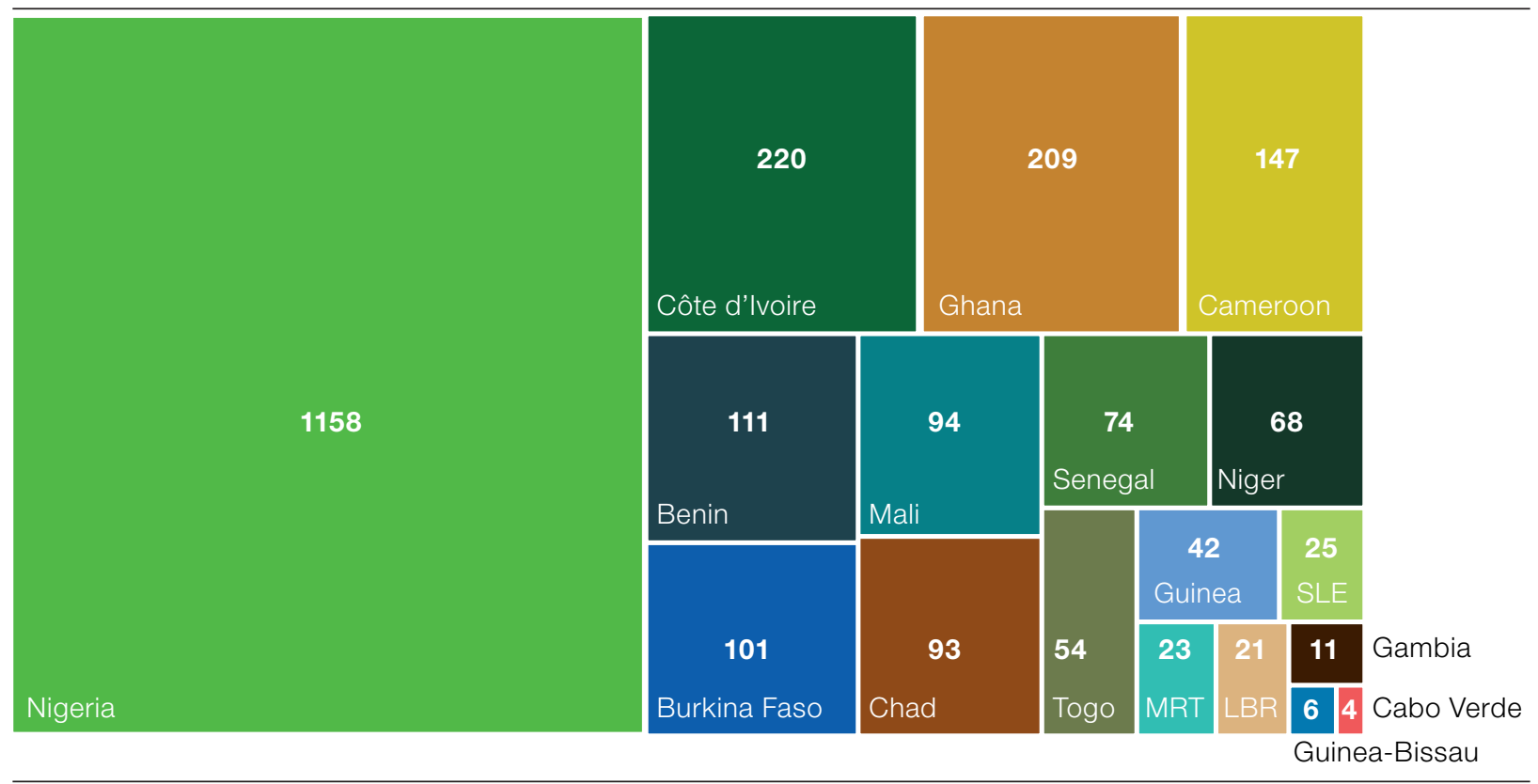

Source: OECD/SWAC 2018

those countries (OECD/SWAC, 2018). Guinea-Bissau, Côte d'Ivoire, Mauritania, Chad and Sierra Leone, countries where the urban primacy index ranking is higher than 7, also have an urban network dominated by a single city. Gambia is unique in that its capital city has a smaller population than the largest city in the country. This is due to the fact that most of the urban growth was pushed beyond the narrow and already fully urbanised Banjul peninsula (33000 inhabitants in 2015) to the city of Serrekunda (790000 inhabitants).

The primacy of the urban network is less marked in Benin, Niger and Senegal where the demographic ratio between the cities of Cotonou, Dakar and Niamey and the second largest city in their respective countries, falls between 2.7 and 3.5. In Cabo Verde, Ghana and Nigeria, the cities of Praia, Accra and Lagos are slightly less populated than predicted by theoretical population distribution in relation to the second largest city in each country.

Burkina Faso and Cameroon have a clearly bicephalic urban network, in which two metropolitan areas dominate the other cities. However, demographic predictions show that the importance of the political capitals of both countries will continue to grow over time, as compared with the second largest city in each of the two countries (OECD/SWAC, 2018). With over 2.8 million inhabitants, Ouagadougou will be 3.6 times more populous than Bobo Dioulasso in 2020, whereas the two cities had approximately the same number of inhabitants in 1950. In Cameroon, the city of Yaoundé will double in size, from 2.3 to 4.6 million inhabitants between 2010 and 2020, while the population of Douala will only increase from 2.2 to 3 million. 
Nigeria is the only country with a multicephalic network, in which a number of big cities occupy the upper echelon of the urban hierarchy. The metropolitan areas of Lagos, Kano and Onitsha function as capital cities of the country's three main ethno-linguistic regions (OECD/SWAC, 2018). The presence of high urban densities and numerous cities of varied sizes have been documented since the pre-colonial era in the south-western part of the country where the transatlantic slave trade fostered the urban development of the Yoruba Empire of Oyo and the kingdom of Benin before these areas came to rely on agricultural products such as palm oil. In the north, the urban network of Hausa city-states and the Kanem-Bourno empire in the Lake Chad basin owes its existence, in large part, to regional and trans-Saharan

Box 1.1

Per-country urbanisation levels and human development

Given that cities offer proximity to socio-educational services, better prospects for long-term employment for migrants and their children as well as better living conditions, there is a very strong correlation between urbanisation and human development (Figure 1.2). As such, less urbanised countries such as Niger (17\%), Chad (29\%) and Burkina Faso (29\%) have the lowest Human Development Index (HDI) rankings.

Figure 1.2

Per-country urbanisation levels and human development rankings by country, 2015

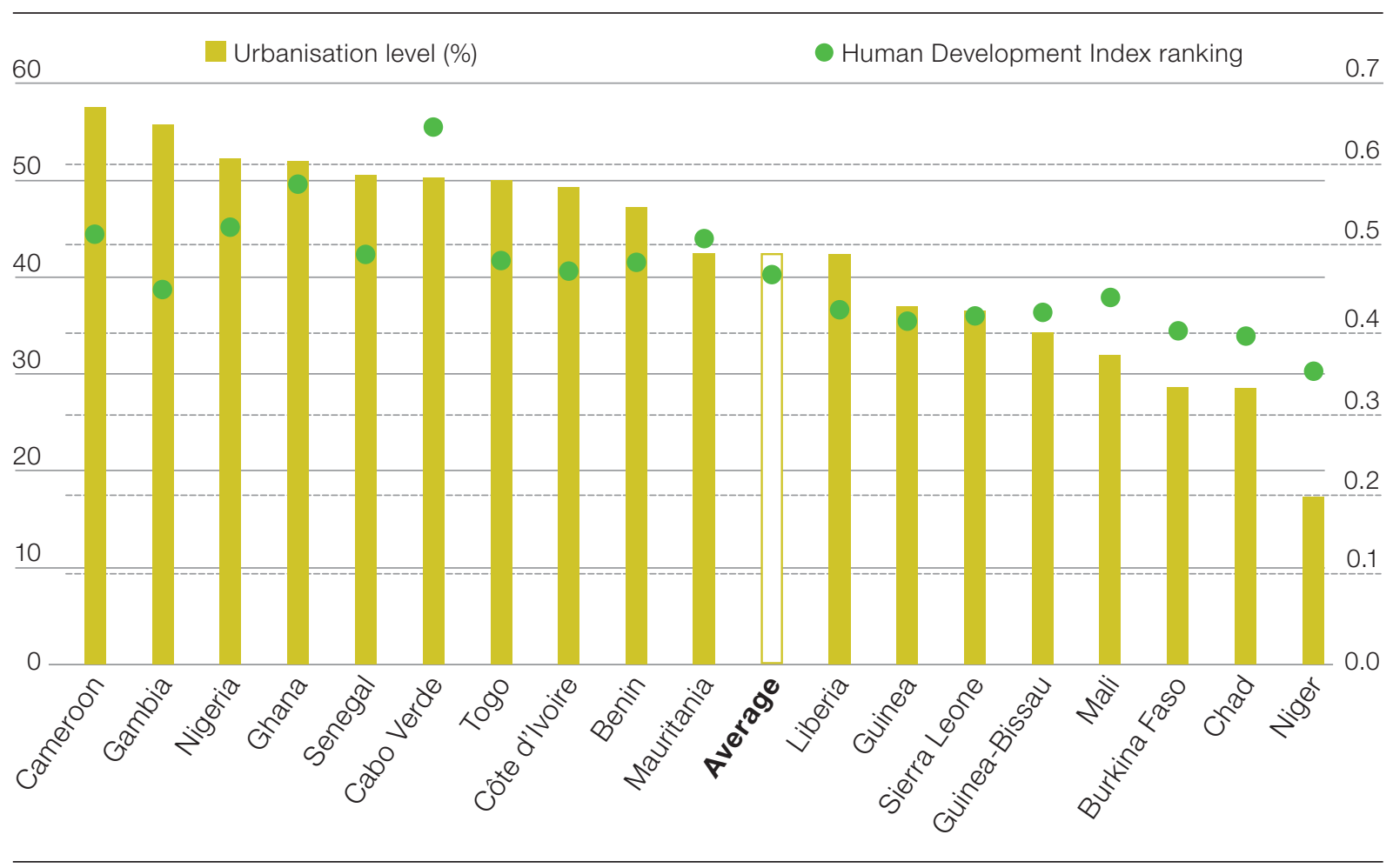

Note: Only cities with more than 10000 inhabitants were included.

Source: OECD/SWAC 2018 
trade. In the southwest, Igbo and Ibibio urbanisation of the Niger Delta and its hinterland has colonial origins.

\section{The size of cities increases with distance from borders}

The West African urban population varies significantly depending on distance from a border. In 2015, cities with more than 10000 inhabitants located less than 20 kilometres from a border accounted for 12 million of the 182 million West African urban inhabitants, or 7\%. Cities situated between 50 kilometres and 100 kilometres from a border accounted for more than 27 million and 65 million inhabitants, or $15 \%$ and $36 \%$ of the urban population, respectively. Of the 2469 cities in West Africa in 2015, close to half were located less than 100 kilometres from a border, 681 less than 50 kilometres and 319 less than 20 kilometres away (Table 1.1).

On average, border cities are smaller than non-border cities. They are also smaller in size than that of the average city in the region. As such, the average population of cities increases with distance from a border, jumping from 37670 inhabitants at 20 kilometres from a border to over 55000 people at 100 kilometres away, while the West African average is greater than 73000 inhabitants. The fact that the median, which breaks the population of cities into two sub-sets of equal size, is much lower than the average for all city categories indicates that more than half of the cities are, in reality, less populated than these average figures indicate. This statistical bias is due to the size of some very large urban centres, such as Lagos, Onitsha, Abidjan or Accra, which increases the average figures.

Table 1.1

Population and number of agglomerations in relation to their distance from a border, 2015

\begin{tabular}{lr|r|r|r|r}
\hline & $20 \mathrm{~km}$ & $50 \mathrm{~km}$ & $100 \mathrm{~km}$ & $>100 \mathrm{~km}$ & $\begin{array}{r}\text { All } \\
\text { agglomerations }\end{array}$ \\
\hline $\begin{array}{l}\text { Population } \\
\text { Average } \\
\text { population }\end{array}$ & 12016669 & 27382565 & 65242901 & 116820097 & 182062998 \\
\hline $\begin{array}{l}\text { Median } \\
\text { population }\end{array}$ & 17045 & 18445 & 18881 & 20810 & 73740 \\
\hline $\begin{array}{l}\text { Number of } \\
\text { agglomerations }\end{array}$ & 319 & 40209 & 55621 & 90231 & 19942 \\
\hline
\end{tabular}

Note: Eight locations with less than 10000 inhabitants were included in the calculations as they are transnational in nature (Amdalai, Dakola, Kofi Badu Krom, Kemerida, Hamele, Deregbe NGA, Hamile and Chikanda NGA). Source: OECD/SWAC 2018 
Figure 1.3

Number and population of agglomerations, based on size in 2015

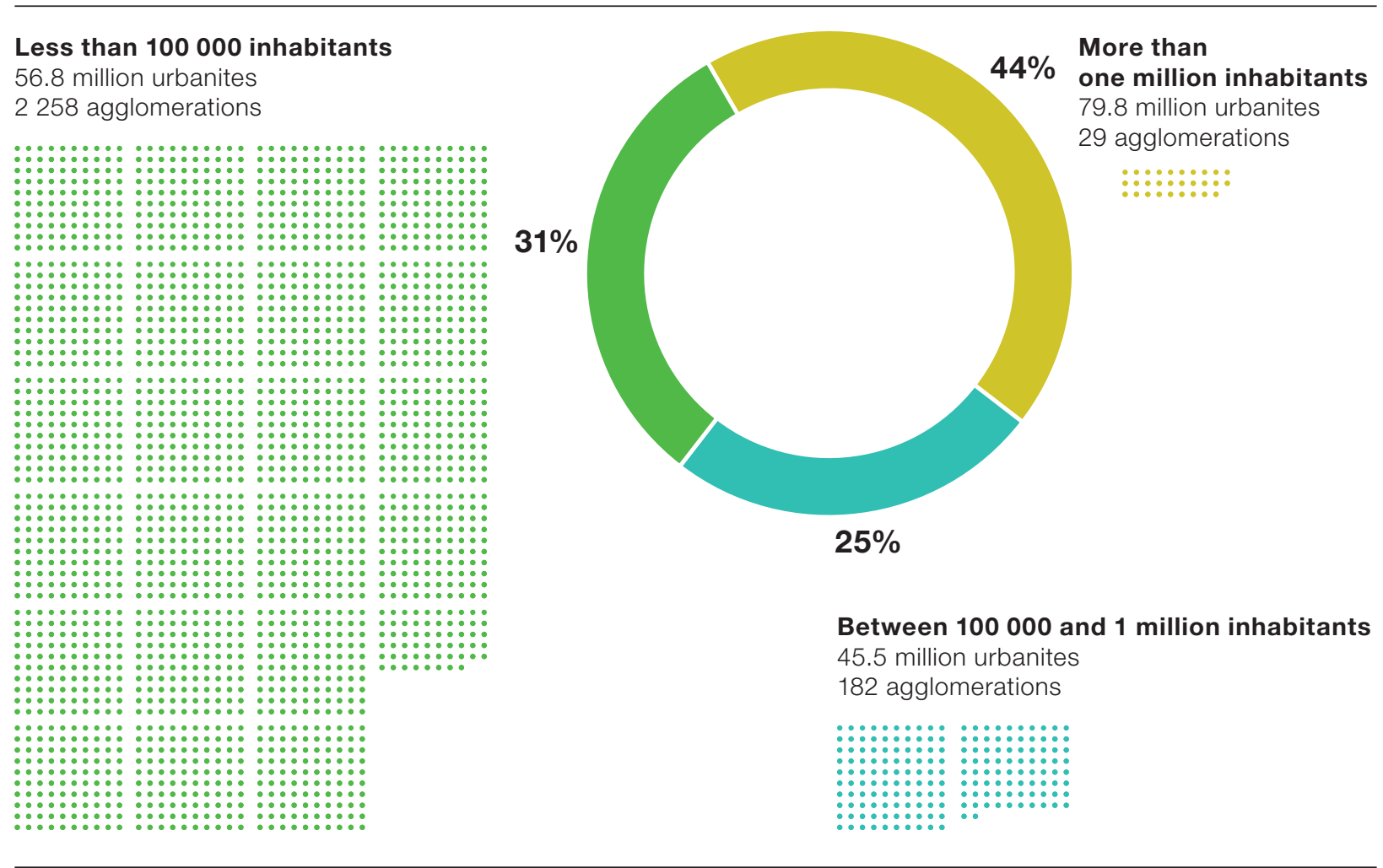

Source: OECD/SWAC 2018

The 29 million-inhabitant cities in the region account for 80 million people, or $44 \%$ of the total urban population. That is nearly two times greater than the population of the 182 cities with between 100000 and 1 million inhabitants (25\%) which account for some 45 million people. Some primate cities are located near a border: less than 100 kilometres, as the crow flies, separate Conakry, Lomé, Bissau, N’Djamena, Freetown, Niamey and Cotonou from a national border. The 2258 cities of less than 100000 inhabitants are home to close to 57 million people, or 31\% of the region's urban population (Figure 1.3).

The urban heterogeneity of border areas is quite high. While some border segments feature a dense network of cities that vary in size, other border areas are almost devoid of cities, for example the northern Guinean borders and some sections of Mali's borders (Map 1.1). At the scale of West Africa as a whole, the largest concentrations in 2015 were seen on the perimetres of Nigeria and the borders of Côte d'Ivoire, Ghana, Togo and Benin ending at the Gulf of Guinea. Due to the narrow shape of their national territory, all cities in Gambia, Guinea-Bissau and Togo are located less than 100 kilometres from a land border. Only two cities in Benin - Gourou and Sékéré-Gando are located further from a border. 
Table 1.2

Cities and urban population per country, based on distance from a border, 2015

\begin{tabular}{|c|c|c|c|c|c|c|}
\hline \multirow[b]{2}{*}{ Country } & \multicolumn{2}{|c|}{$20 \mathrm{~km}$} & \multicolumn{2}{|c|}{$50 \mathrm{~km}$} & \multicolumn{2}{|c|}{$100 \mathrm{~km}$} \\
\hline & Cities & Population & Cities & Population & Cities & Population \\
\hline Benin & 41 & 1610341 & 88 & 4408260 & 109 & 5043126 \\
\hline Burkina Faso & 11 & 176821 & 37 & 679923 & 67 & 1489425 \\
\hline Côte d'Ivoire & 19 & 433303 & 43 & 1140115 & 103 & 3093656 \\
\hline Cameroon & 27 & 676772 & 47 & 1360639 & 86 & 2893994 \\
\hline Gambia & 9 & 285298 & 12 & 1127487 & 12 & 1127487 \\
\hline Ghana & 28 & 786616 & 60 & 1711124 & 106 & 2975683 \\
\hline Guinea & 8 & 417743 & 14 & 794149 & 33 & 3773535 \\
\hline Guinea-Bissau & 0 & 0 & 3 & 70494 & 6 & 525458 \\
\hline Liberia & 6 & 149061 & 12 & 304952 & 14 & 333041 \\
\hline Mali & 14 & 211267 & 25 & 702434 & 51 & 1619821 \\
\hline Mauritania & 5 & 241868 & 9 & 342885 & 13 & 448429 \\
\hline Niger & 12 & 305301 & 34 & 1077128 & 53 & 2741092 \\
\hline Nigeria & 60 & 1782476 & 159 & 6619608 & 335 & 28427955 \\
\hline Senegal & 23 & 611292 & 41 & 1347176 & 50 & 1873654 \\
\hline Sierra Leone & 5 & 96682 & 11 & 337367 & 19 & 2492201 \\
\hline Chad & 20 & 1652371 & 31 & 1938647 & 61 & 2964167 \\
\hline Togo & 31 & 2579457 & 55 & 3420177 & 55 & 3420177 \\
\hline Total & 319 & 12016669 & 681 & 27382565 & 1173 & 65242901 \\
\hline
\end{tabular}

Source: OECD/SWAC 2018

The numeric and demographic weight of Nigerian cities is remarkable, no matter their distance from a border (Table 1.2). The 60 Nigerian cities located 20 kilometres from a border account for 19\% of the number of cities and $15 \%$ of the region's urban border population. This percentage increases significantly with distance. One-quarter of Nigeria's cities and border population are located less than 50 kilometres from a border. The 335 Nigerian border cities located less than 100 kilometres from a border account for close to $44 \%$ of the urban population included in the study, or over 28 million people. 
Map 1.1

Agglomerations and their distance from a border, 2015

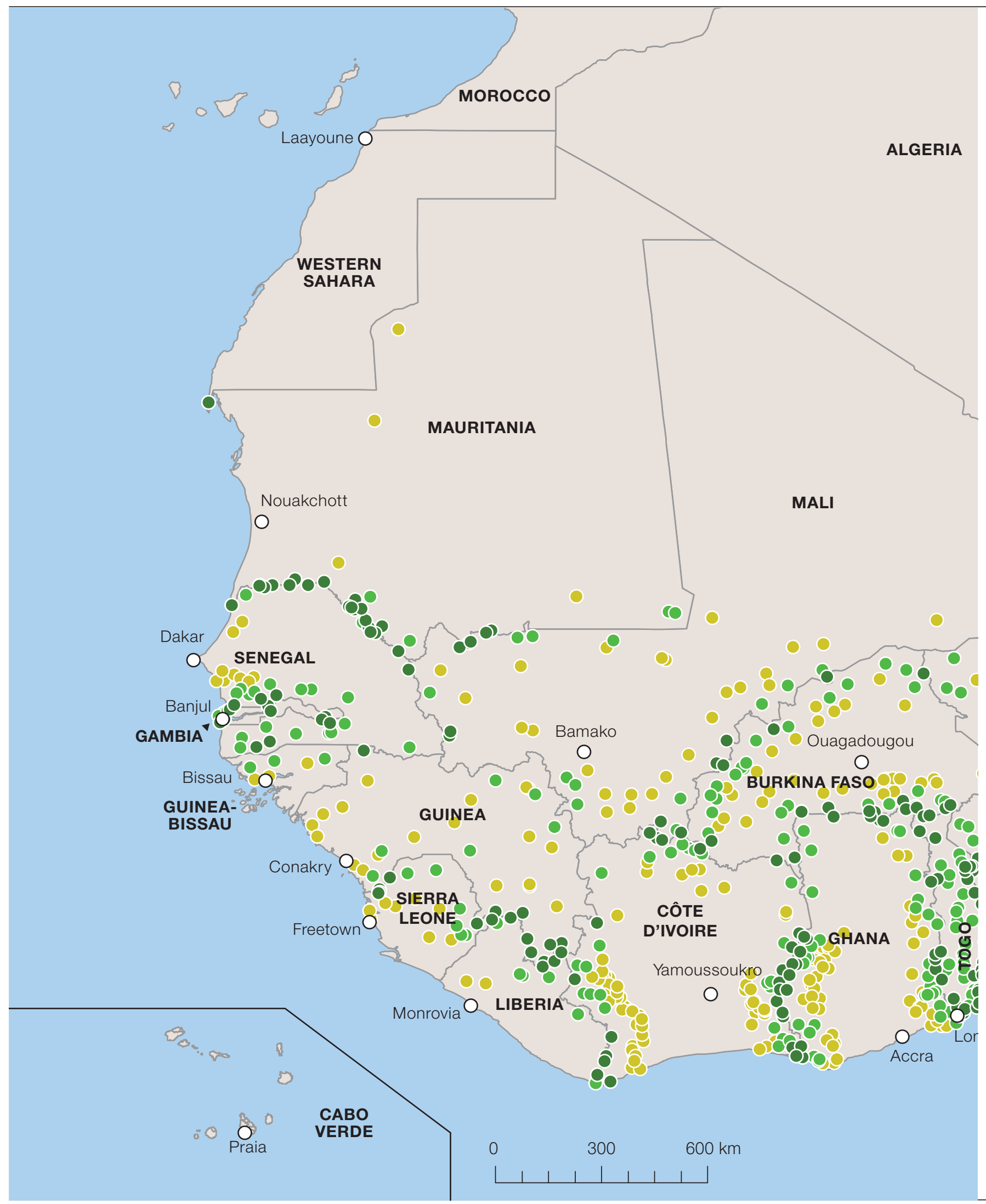




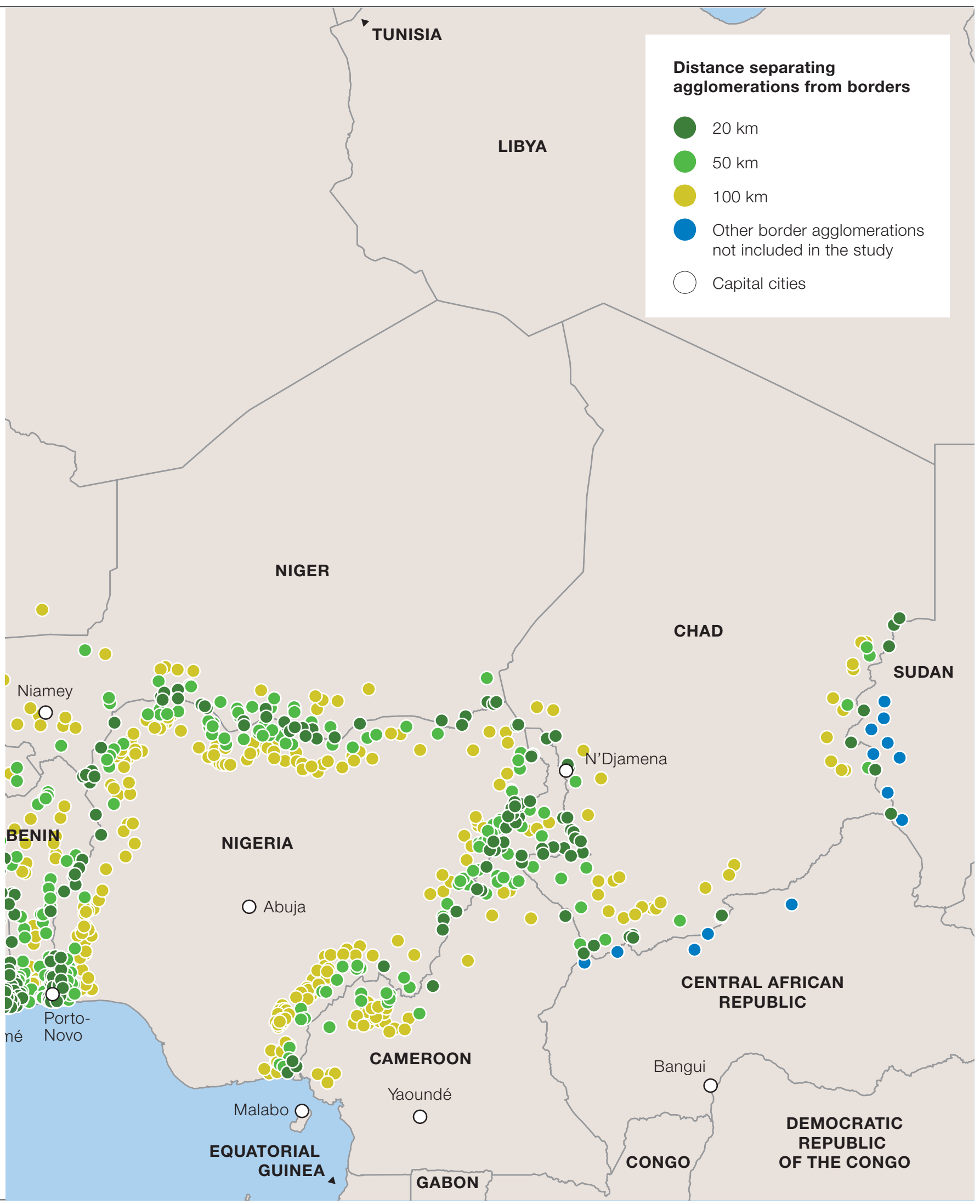


Map 1.2

Urban border population at $20 \mathrm{~km}$ from a border, 2015

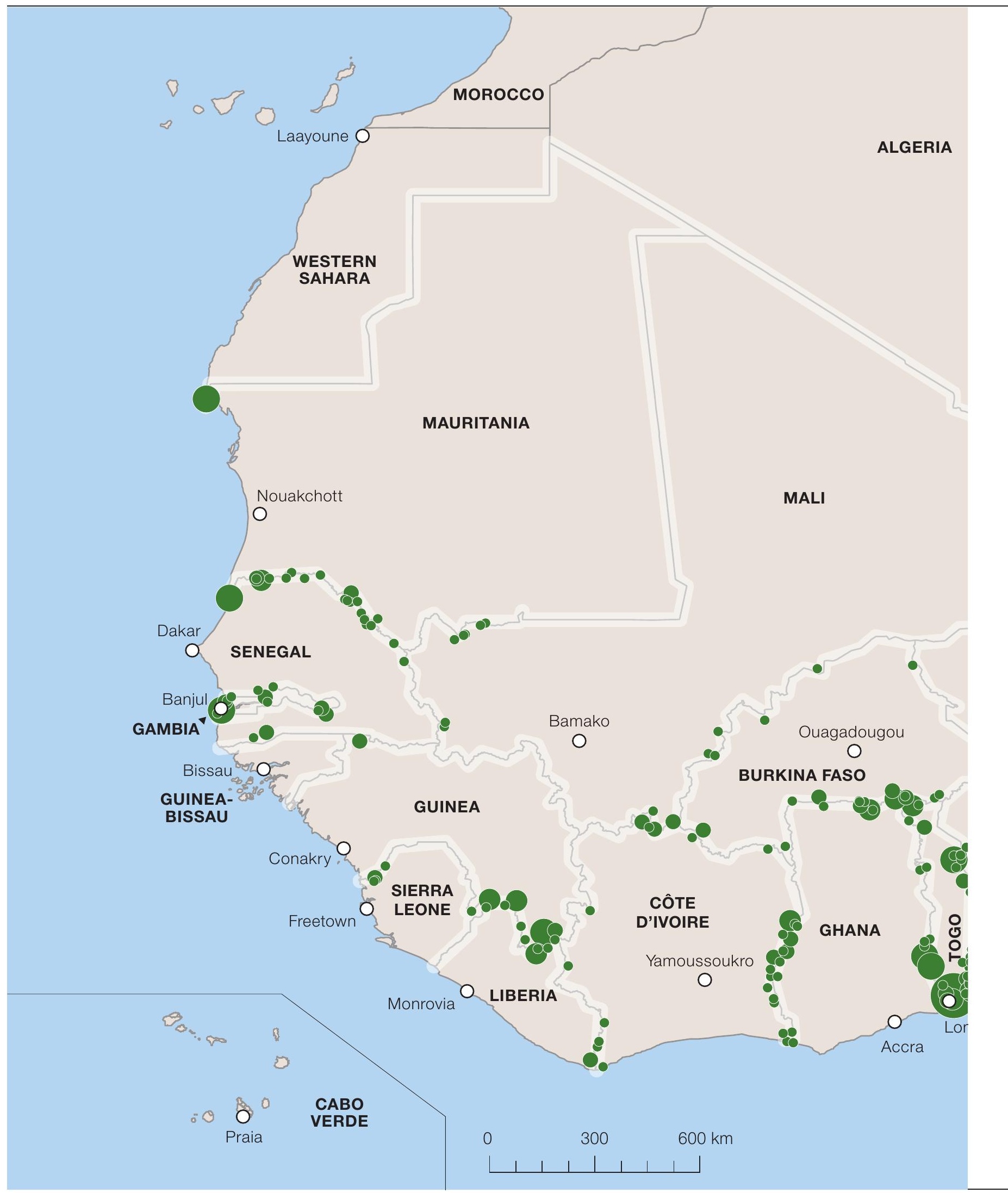




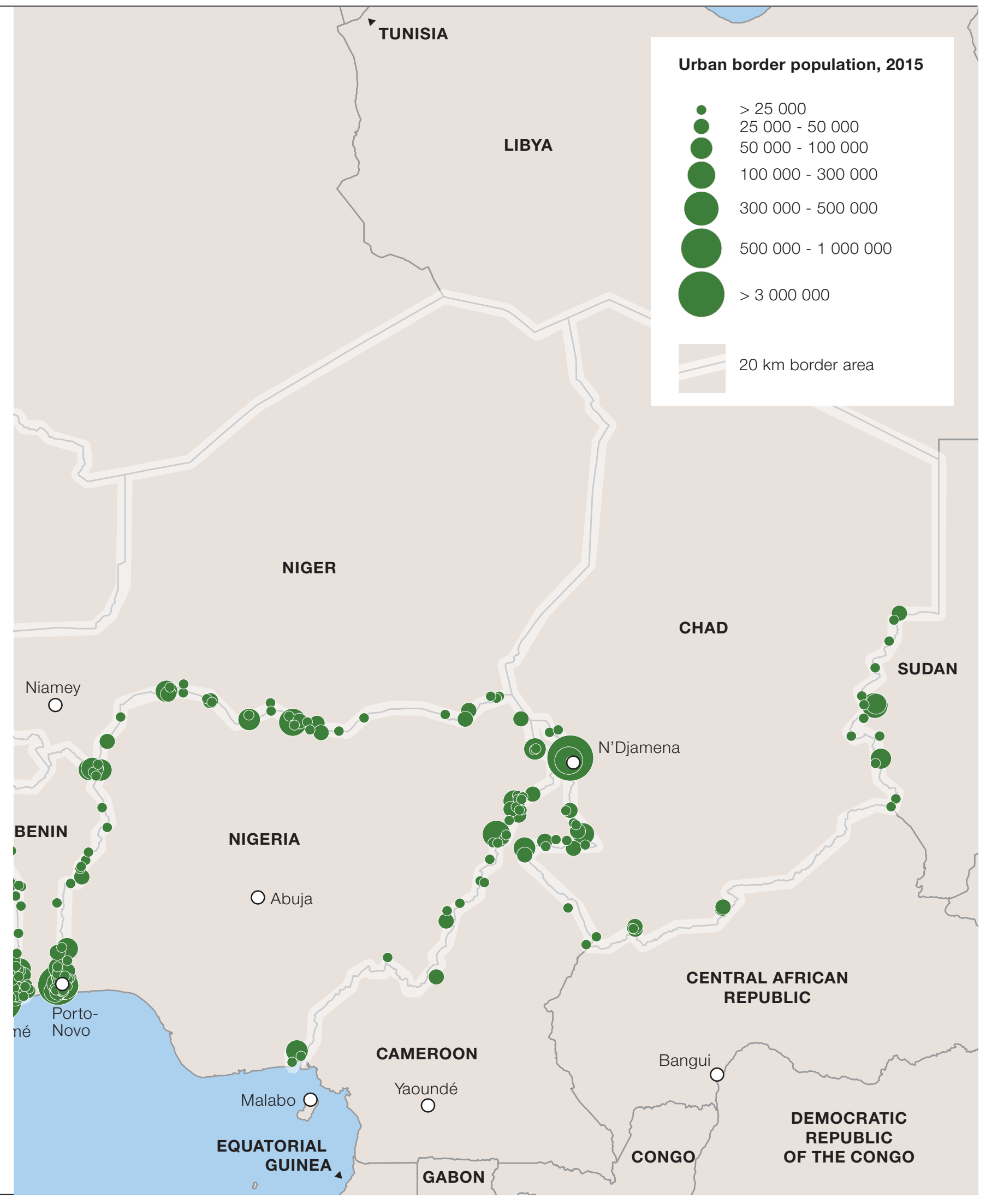


The percentage located in Togo and Benin, which is high at between 20 and 50 kilometres from a border, decreases significantly as distance from a border increases and accounts for only 5 and 8\% of the population at 100 kilometres. This is due to the narrow shape of the national territory.

The map of the urban network at 20 kilometres sheds light on the demographic weight of small- and medium-sized border cities (Map 1.2). At that distance from a border, only 14 of 319 cities have a population of more than 100000 people (4\%) and only Lomé and N'Djamena have more than one million inhabitants. Close to seven of ten border cities are small centres inhabited by less than 25000 people whose activities are often linked to cross-border trade as in Rosso, Senegal; Paga, Ghana; and Cinkansé, Burkina Faso. In the Sahel, there are more border cities in the western part of the Senegal River valley, Hausaland and the Lake Chad region. Conversely, there are no border cities along large sections of West Africa's borders. This is true for Saharan lands where cities are rare in general, almost all of Mali's Sahelian and Sudanian borders as well as the borders of northern Guinea and northern Burkina Faso.

At 50 kilometres from a border, the urban landscape is always dominated by an abundance of small-and medium-sized cities. As such, cities with less than 25000 inhabitants account for $65 \%$ of the number of cities and just under one-quarter of the total urban population. The percentage of cities with over 100000 inhabitants was still quite low (6\%) in 2015 (Map 1.3). Other than the capital cities of Togo and Chad, Cotonou, Benin, is the only city with over 1 million people; its population in 2015 was 1.5 million inhabitants. Lower down on the urban hierarchy, Serrekunda, Gambia; Porto-Novo, Benin; and Calabar, Nigeria have more than half a million people. The combined population of these cities with more than half a million inhabitants accounts for $25 \%$ of urban dwellers living in the region's border areas. The disparities noted within the region at 20 kilometres persist at 50 kilometres: the Nigerian borders, the Gulf of Guinea between Ghana and Benin, and the southern portion of the Lake Chad basin appear to be exceptional clusters, while large sections of the borders have few urban areas, as is the case between Mali and its neighbours.

In 2015, there were seven cities with more than 1 million inhabitants located at less than 100 kilometres from a border (Map 1.4): Lomé, N'Djamena and Cotonou (already mentioned) as well as Lagos, Conakry, Freetown and Niamey. The population of these cities accounts for one-third of the total urban border population, or 21 million urban dwellers, 12 million of whom live in Lagos. The relationship between borders and these million-inhabitant cities is more tenuous than at 20 or 50 kilometres away due to the other administrative and political functions they serve. While Lagos, N'Djamena, Cotonou and Lomé are firmly entrenched in regional cross-border trade thanks to their transportation infrastructure, large urban markets and specialised traders, the presence of a relatively close border influences to a lesser degree the 
Figure 1.4

Per-country average annual urban growth, 1950-2015

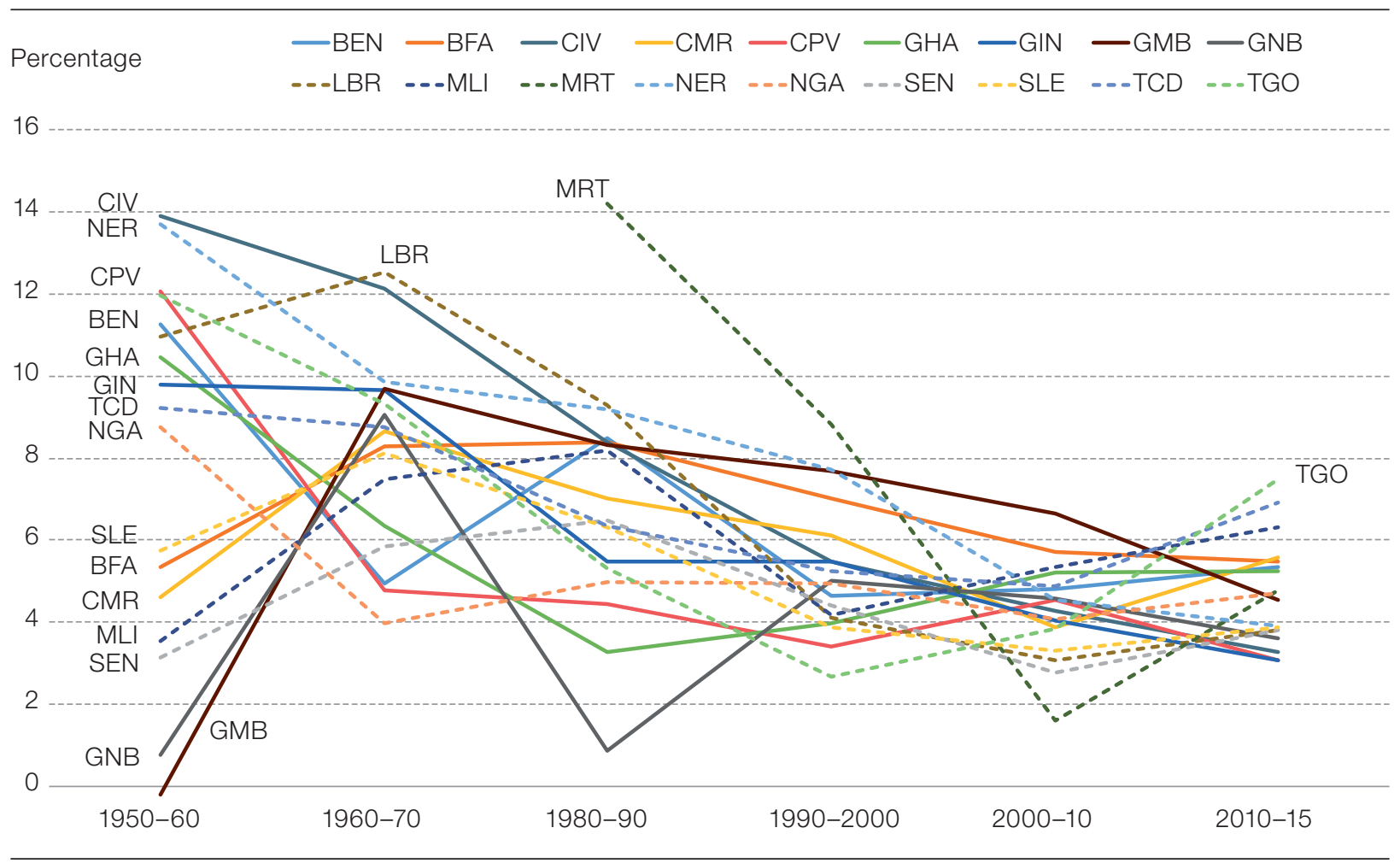

Source: OECD/SWAC 2018

urban development of Conakry, Freetown and Niamey. These cities clearly function as the main entry point for national imports and exports; they are more closely connected to the world by international trade than to borders areas via the re-export or contraband trade.

\section{Border cities are growing more quickly than others}

In many West African countries strong urban growth predates the decolonisation process of the 1960s (Coquery-Vidrovitch, 1993; OECD/SWAC, 2018). Between 1950 and 1960, the urban population of Côte d'Ivoire, Niger, Liberia, Cabo Verde, Togo, Benin and Ghana grew at an annual rate of more than $10 \%$, or the equivalent of a two-fold population increase in less than seven years (Figure 1.4). In Sierra Leone and Cameroon, the highest rates of growth were seen between 1960 and 1970. Starting in 1970, the annual growth rate of cities in the region dropped in most countries before stabilising at between 3 and $6 \%$ in the current decade.

Demographic growth has been especially high in the capital cities where administrative activities and colonial as well as post-colonial economic services are concentrated. These capital cities, often created from small market towns or from scratch, quickly outdistanced the old centres of power. 
Map 1.3

Urban border population at $50 \mathrm{~km}$ from a border, 2015

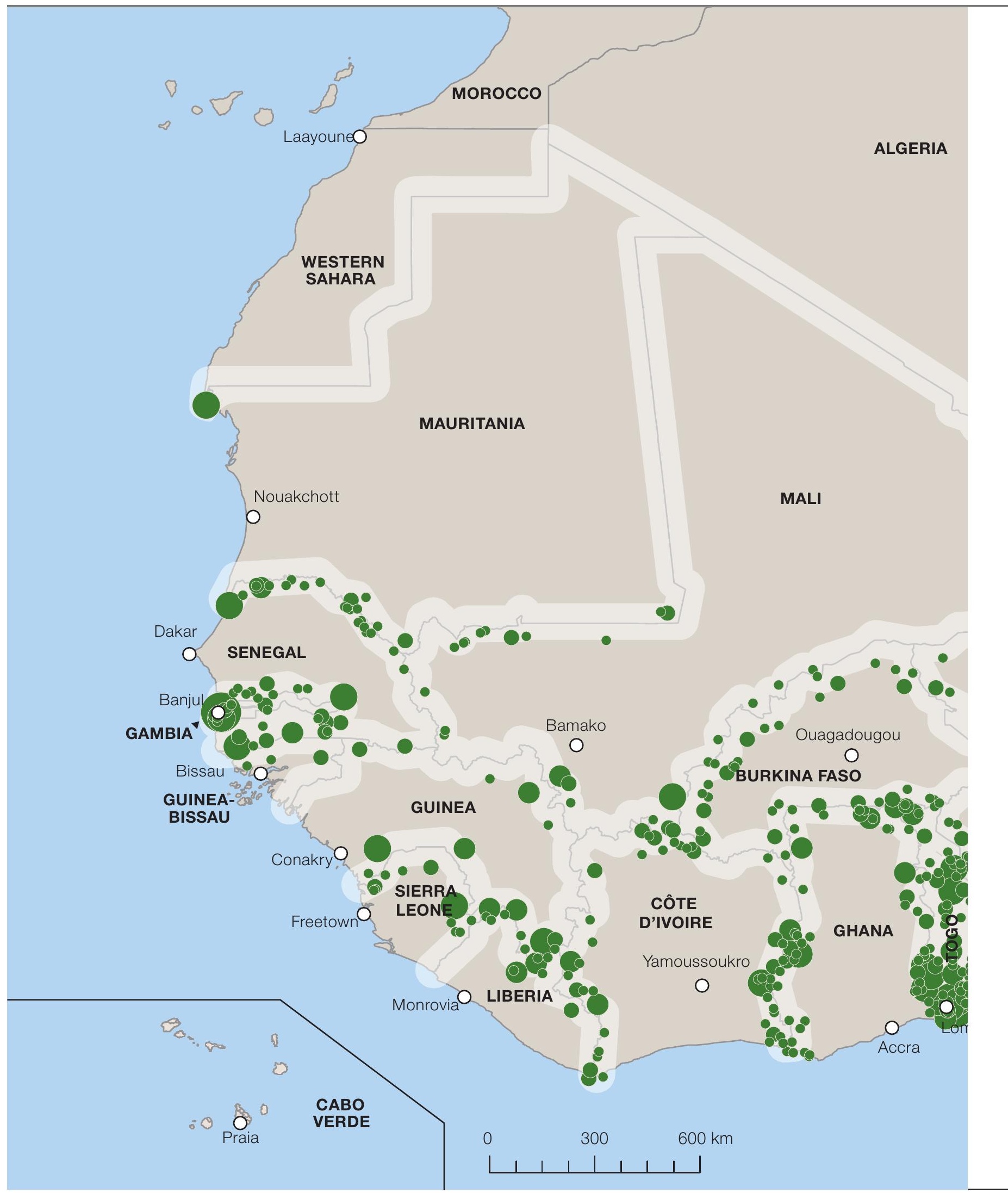




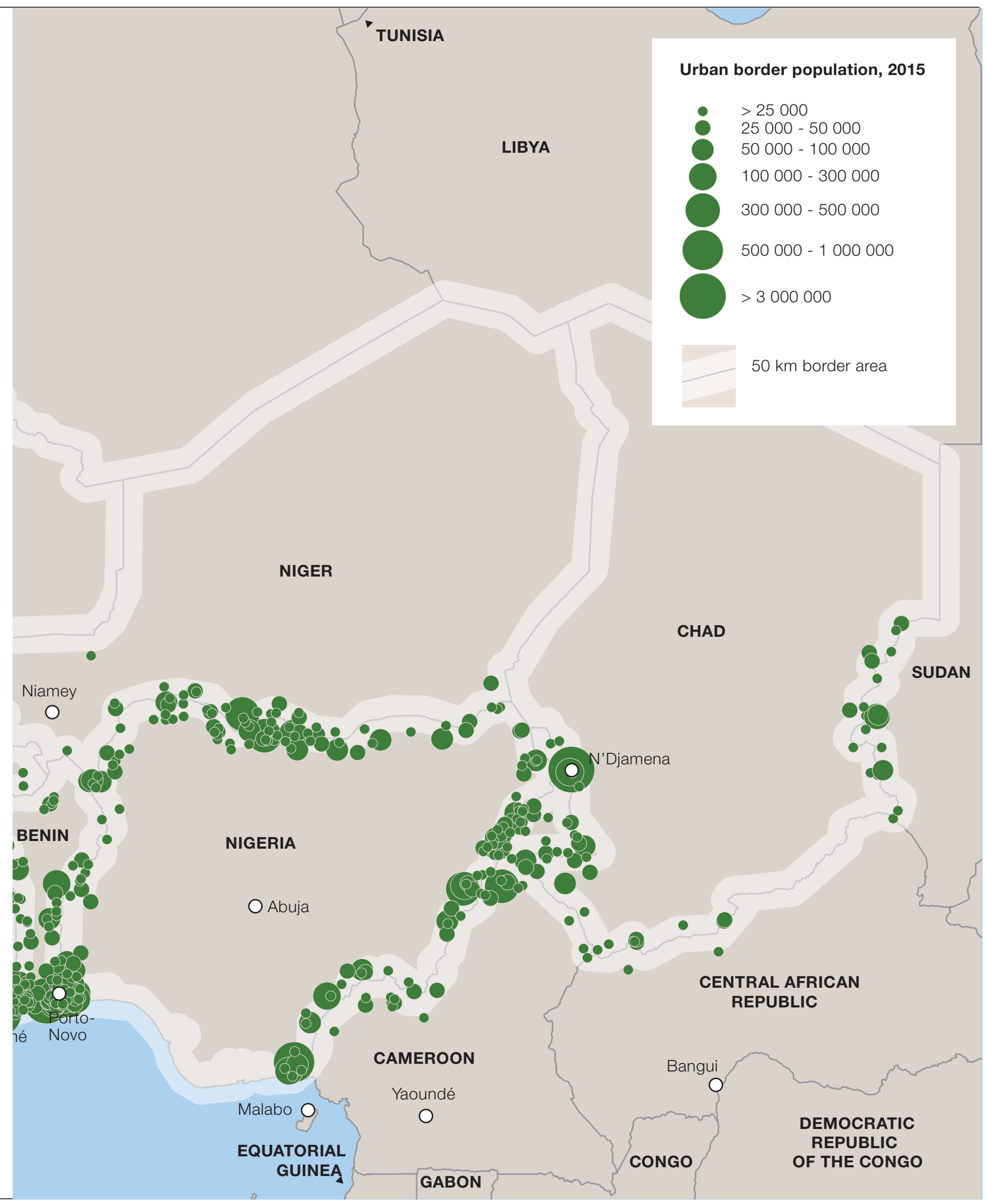


Map 1.4

Urban border population at $100 \mathrm{~km}$ from a border, 2015

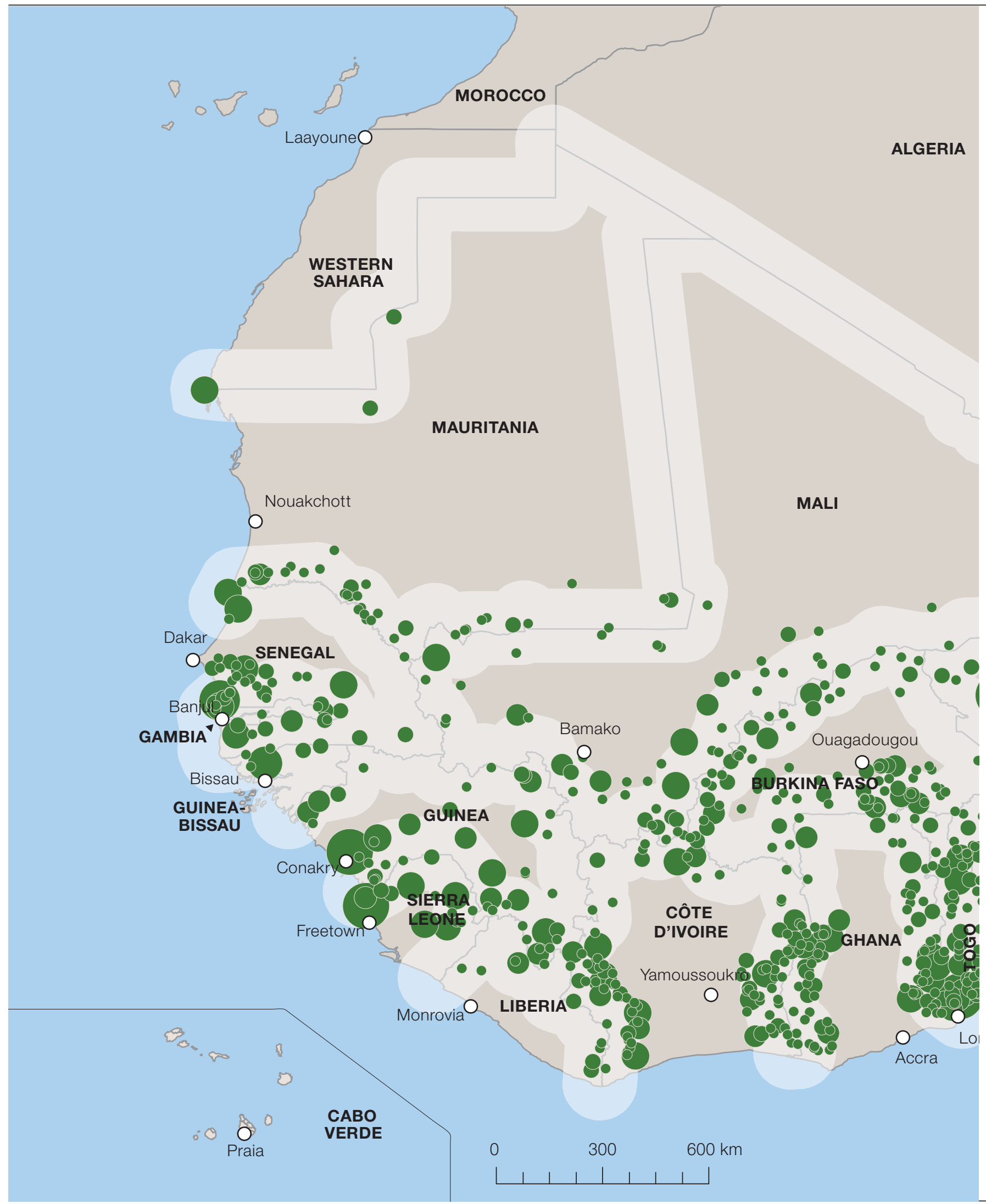




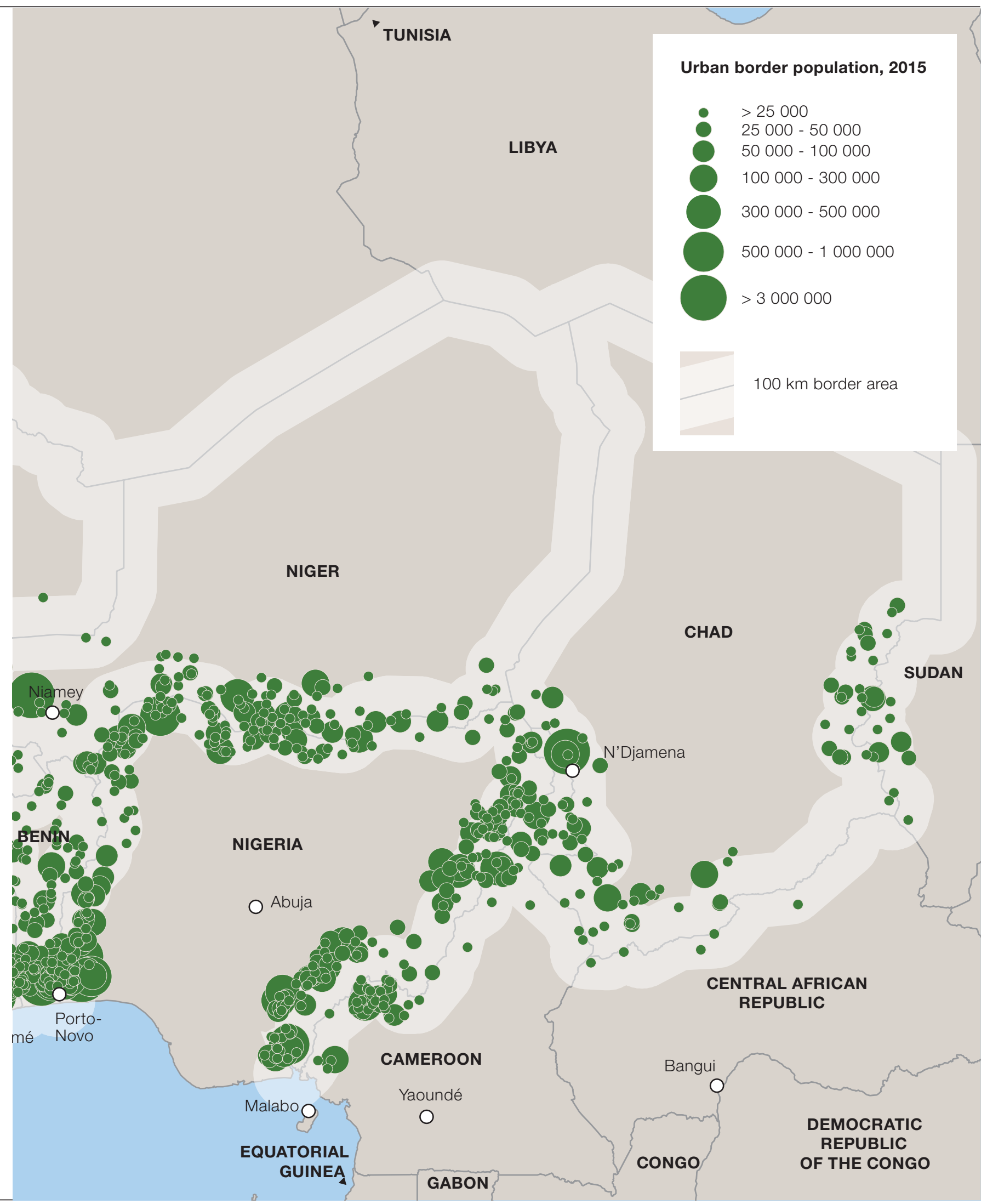


Figure 1.5

Demographic changes in the capital and secondary agglomerations of Niger, Mali and Senegal, 1910-2015

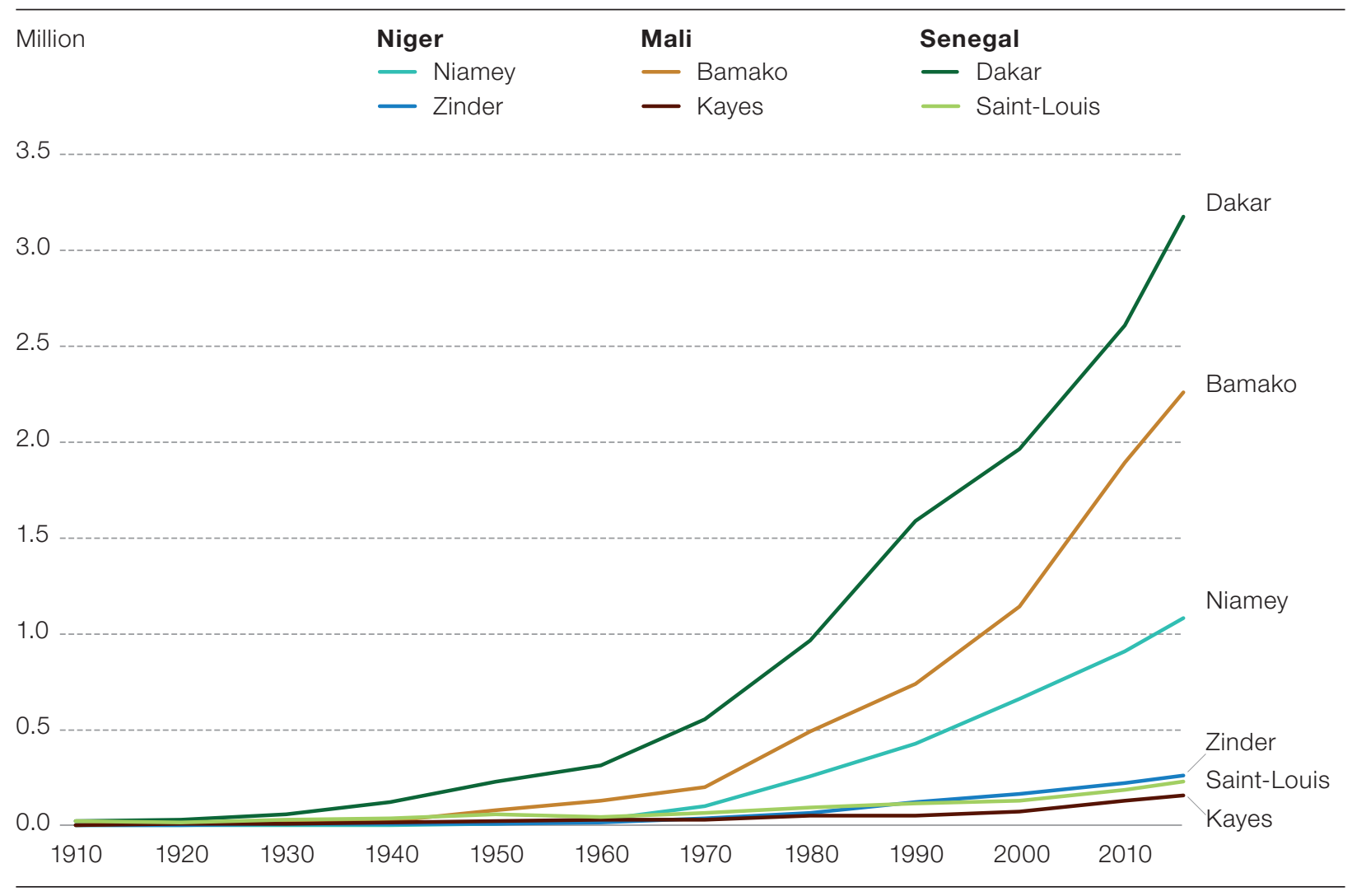

Source: OECD/SWAC 2018

For example, Niamey, Niger, was home to less than 10000 people in 1950 as compared with 12000 in Zinder, the historic capital city of the Damagaram Sultanate. When the country gained its independence in 1960, the new political capital had 33000 inhabitants, while Zinder had a population of less than 20000. The population of Niamey is estimated to exceed 1.2 million people by 2020, which would be equivalent to almost 5.5 times the size of the country's second largest city. A similar change is taking place in Mali and Senegal, where Bamako and Dakar surpassed the size of Kayes and Saint-Louis well before decolonisation, as seen in Figure 1.5, which presents a comparison of the demographic changes in these cities since 1910.

Strong demographic growth has also been seen in border areas. The most spectacular growth has been observed in the corridors nearest the borders. Cities located less than 20 kilometres from a border were home to 260000 people in 1950, as compared with 16 million by 2020, or 62 times higher. The number of urban dwellers living less than 50 kilometres from a border grew by a factor of 60 in the same time period, going from just over half a million to 33 million people. At a distance of 100 kilometres, the border population has grown by a factor of 50, and by 2020 the population 
Figure 1.6

Urban population based on distance from a border, 1950-2015

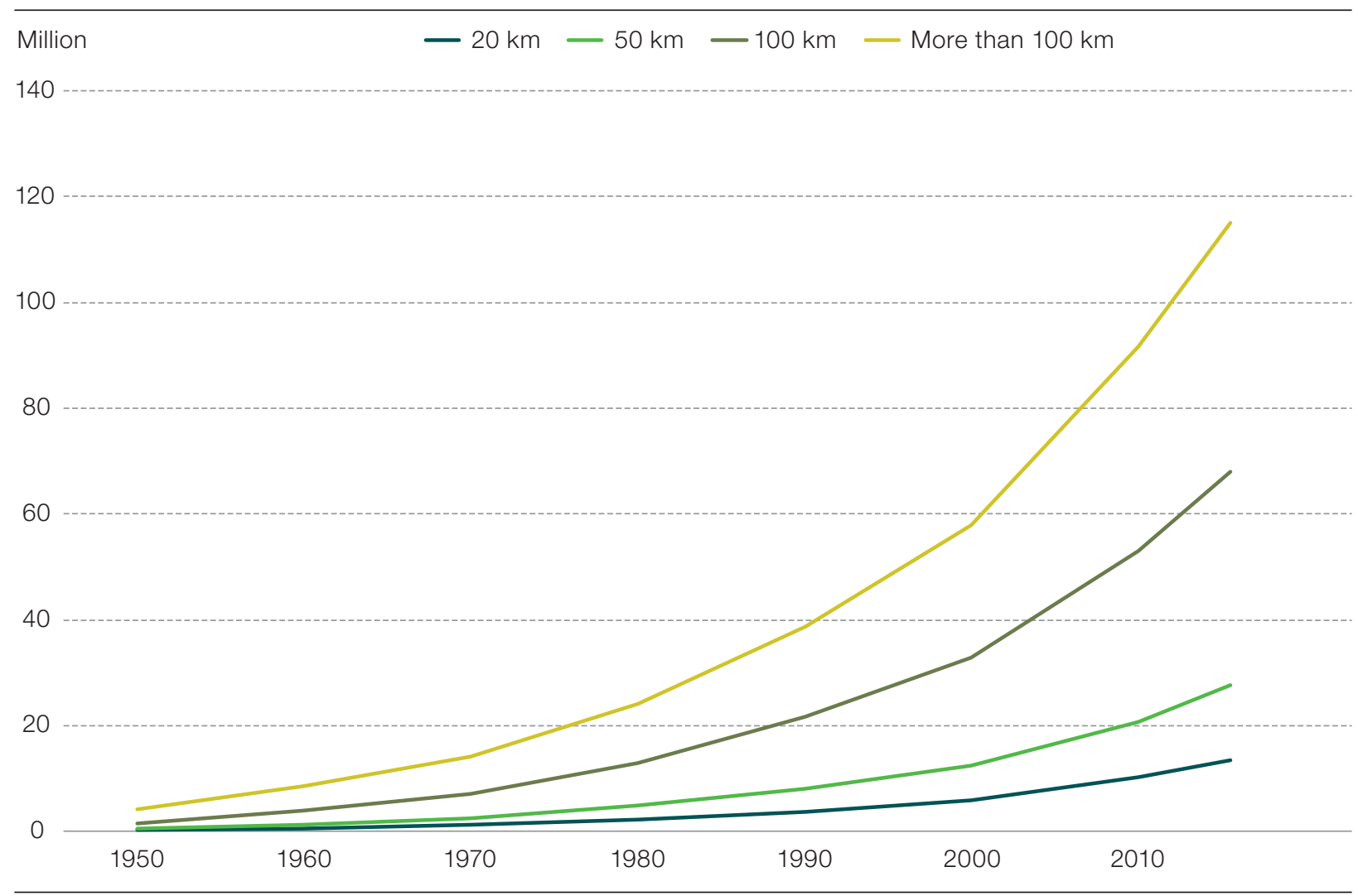

Note: Only countries with a land border were included.

Source: OECD/SWAC 2018

is projected to reach 80 million as compared with a mere 1.6 million prior to the 1960s (Figure 1.6).

In recent decades, the average annual growth of border cities has been consistently higher than that of other cities in the region (Figure 1.7). Having far surpassed 8\% in the 1950s, it decreased gradually in recent decades before reaching between 4 and 5\%, depending on distance from a border. As such, the average growth rates show that areas located immediately adjacent to a border (between 0 and 50 kilometres), are generally more likely to experience demographic growth. In addition to internal demographic growth due to a high birth rate, these cities attract many entrepreneurs seeking to benefit from cross-border differentials.

Consequently, of the entire West African urban population, the percentage of border cities has increased considerably over time. In 1950, only $4.6 \%$ of the urban population lived less than 20 kilometres from a border. By 2010, that percentage had increased to 7.1 and is expected to reach $7.5 \%$ by the end of the decade. By 2020, one-sixth of the region's urban dwellers will live less than 50 kilometres from a border, as compared with 10\% in 1950. More 
Figure 1.7

Average annual growth of agglomerations based on distance from a border, 1950-2015

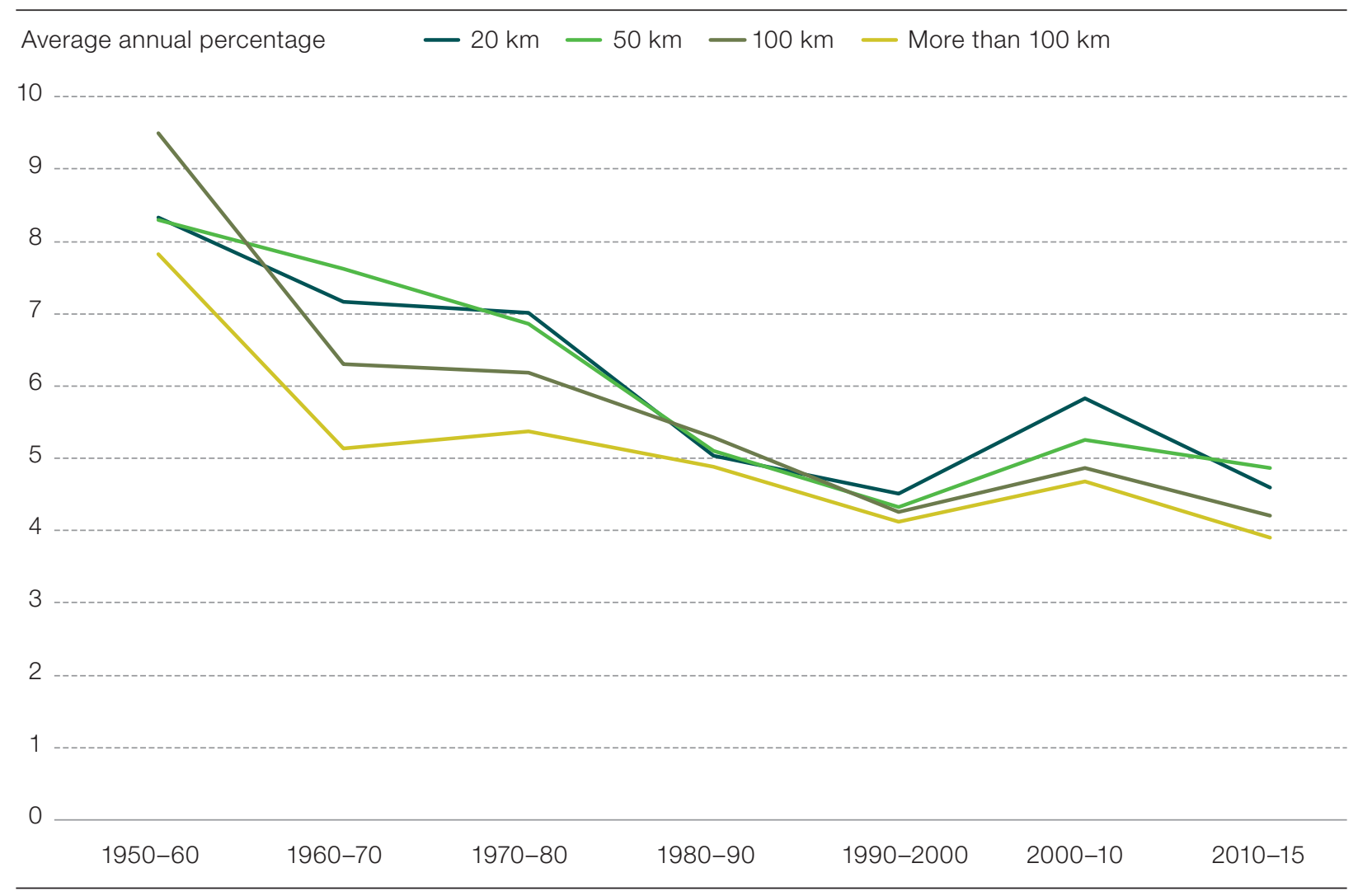

Note: Only countries with a land border were included.

Source: OECD/SWAC 2018

than one-third of West Africa's urban population (37\%) will live less than 100 kilometres from a border by 2020 (Figure 1.8).

While general demographic growth at the regional level has been spectacular, the figures for border cities mask some geographic disparities. The average growth rate observed between 2000 and 2010 shows only very slight northsouth changes between the Sahel and the Gulf of Guinea, little variation from east to west between Lake Chad and the Atlantic and few national specifics (Map 1.5). On the contrary, cities within the same region or country may grow at very different rates. These disparities reflect one of the paradoxes of border cities: only some of them are actually located on strategic routes or in the centre of production areas that would enable them to benefit from the advantages of a border. Such strategic advantages, which are often local in nature, fluctuate with changes in tax and customs regulations, exchange rates and import policies. Consequently, the demographic evolution of border cities is often erratic.

This heterogeneity can be clearly seen on the Gulf of Guinea between Ghana and Nigeria (Map 1.6). The highest average annual growth in West Africa 


\section{Figure 1.8}

Urban population percentage based on distance from a border, 1950-2010

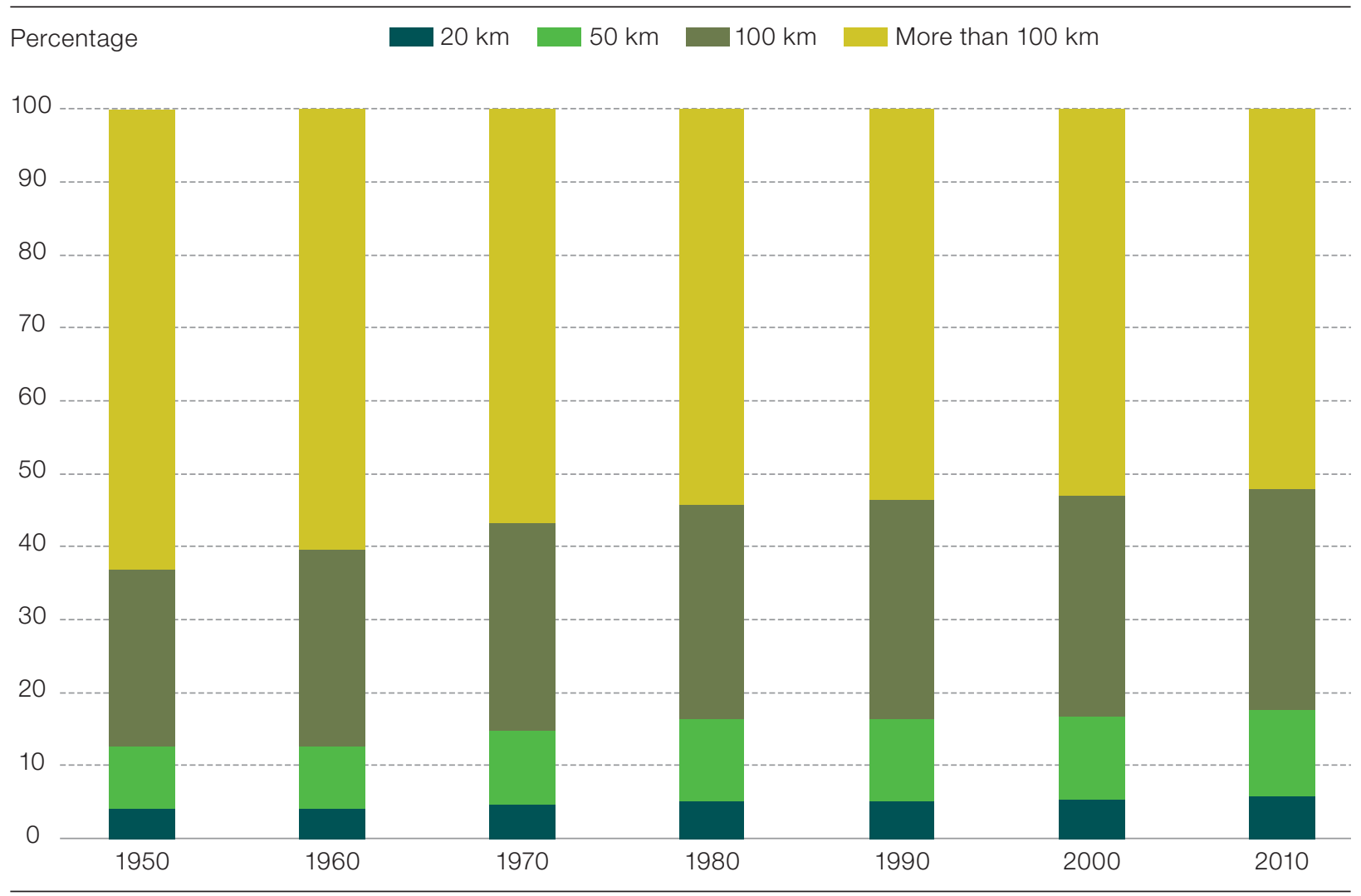

Note: Only countries with a land border were included.

Source: OECD/SWAC 2018

between 2000 and 2010 was observed in Somanya, Ghana (+18.8\%), where the urban population grew from 15600 to 87300 people and in Abomey-Bohicon, Benin (+12.9\%), where the number of inhabitants jumped from 57200 to 192000. Marked differences can also be seen on a smaller scale. While some cities such as Sémé Kpodji and Ekpè grew by more than $5 \%$ annually due to their proximity to Cotonou and their strategic location along the corridor linking Benin with Lagos, other cities on the margins of that central area have grown at a much lower annual rate or experienced negative growth. The population of Idi Iroko, a Nigerian border city, dropped from 36900 to 33300 inhabitants (-1.0\%), while that of Ado Odo (-0.51\%) and Ipokia (-0.55\%) have decreased slightly.

There are similar disparities between Ghana and Togo. The city of Somanya located in the centre of a cluster of large agricultural towns - is located within proximity of many small towns close to the Akosombo Dam that had a much lower average annual growth rate between 2000 and 2010, including Juapong (+2.4\%), Kpong (+0.8\%) and Peki-Tsame (+0.3\%). Further south along the coastal belt, the average annual growth for Lomé (+7.6\%) and Aflao $(+6.5 \%)$, where the population doubled during the period under consideration, 


\section{Map 1.5}

Average annual growth of agglomerations at $100 \mathrm{~km}$ from a border, 2000-10

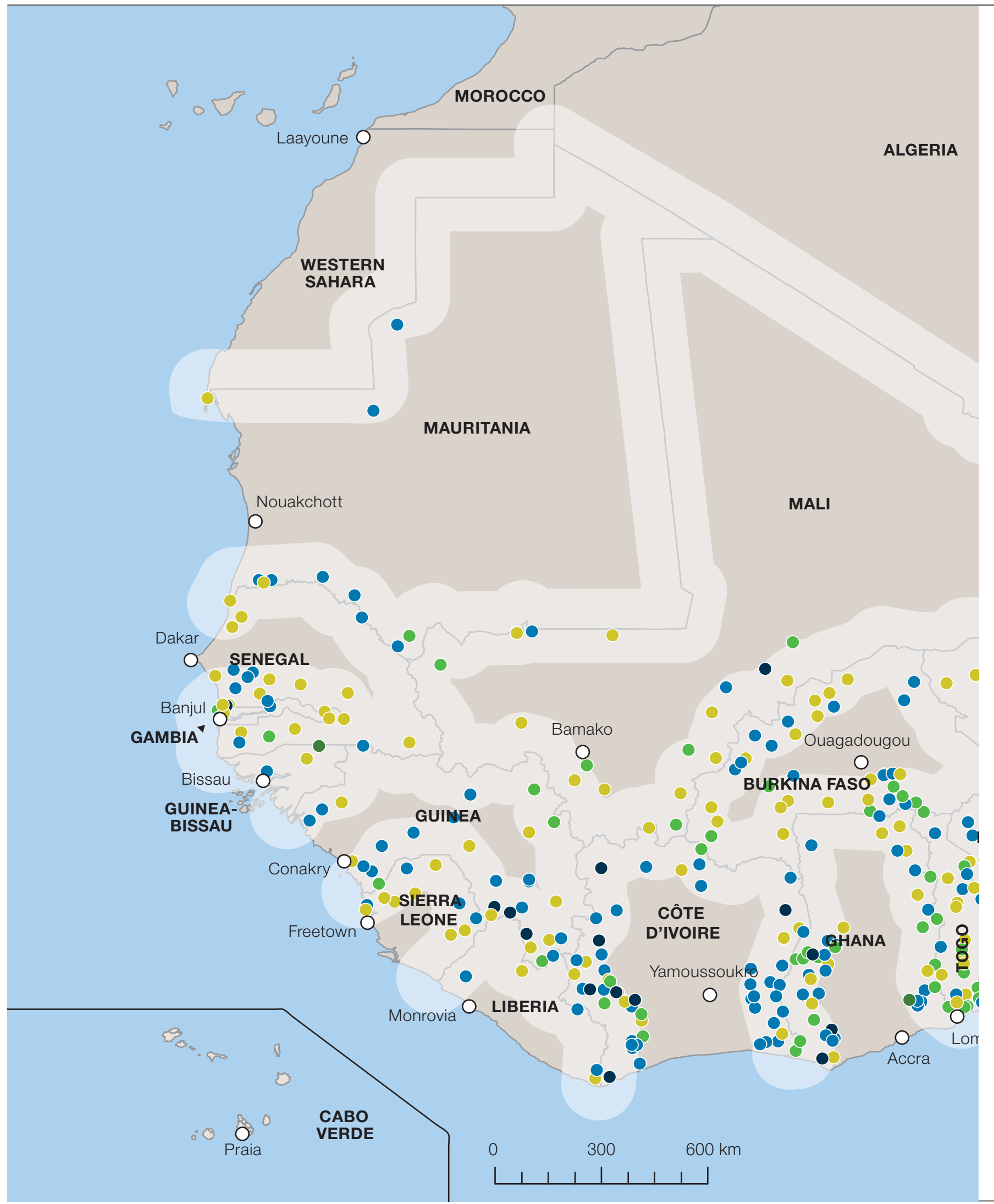




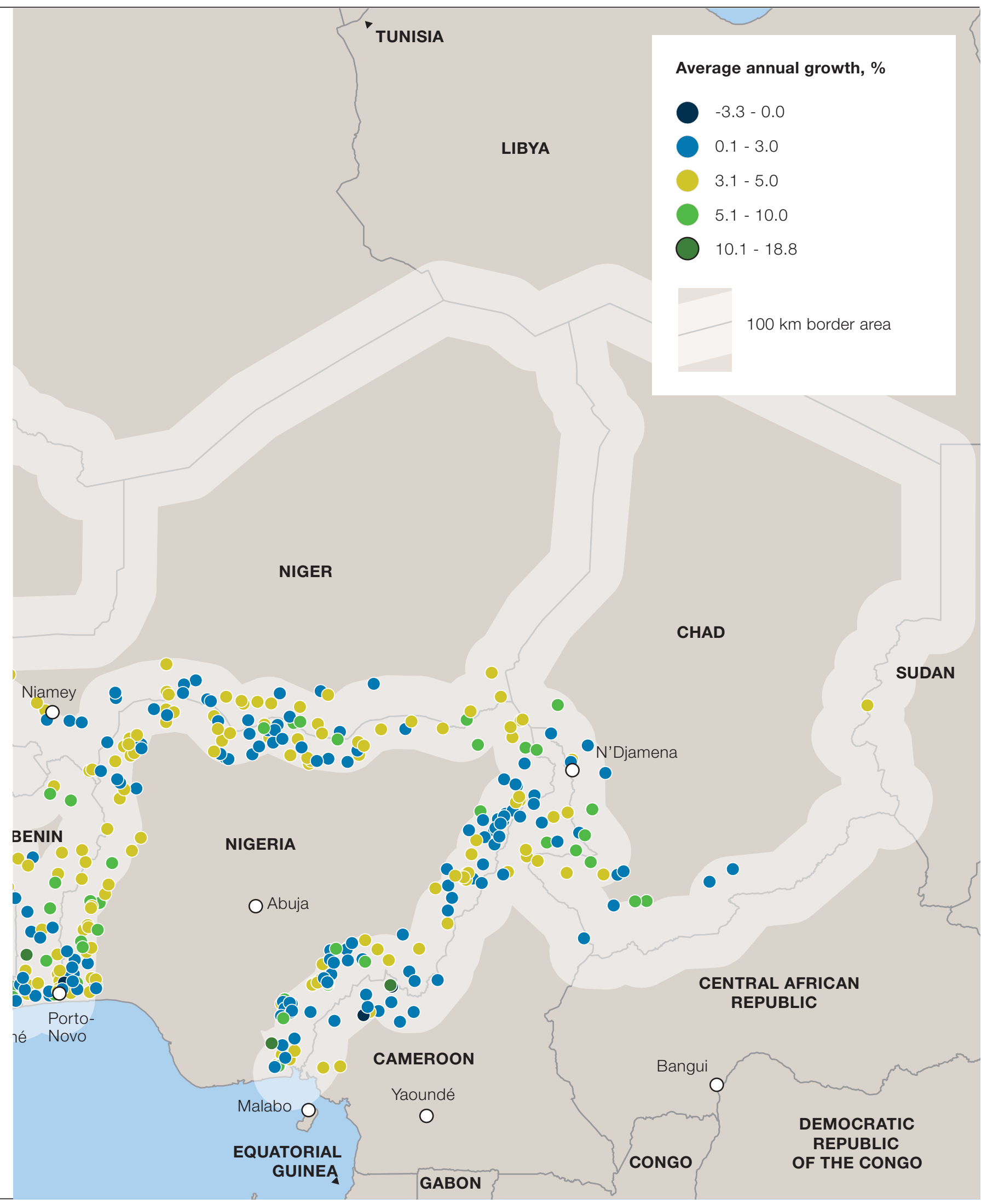




\section{Map 1.6}

Average annual growth of border agglomerations between Ghana and Nigeria at $100 \mathrm{~km}$ from a border, 2000-10

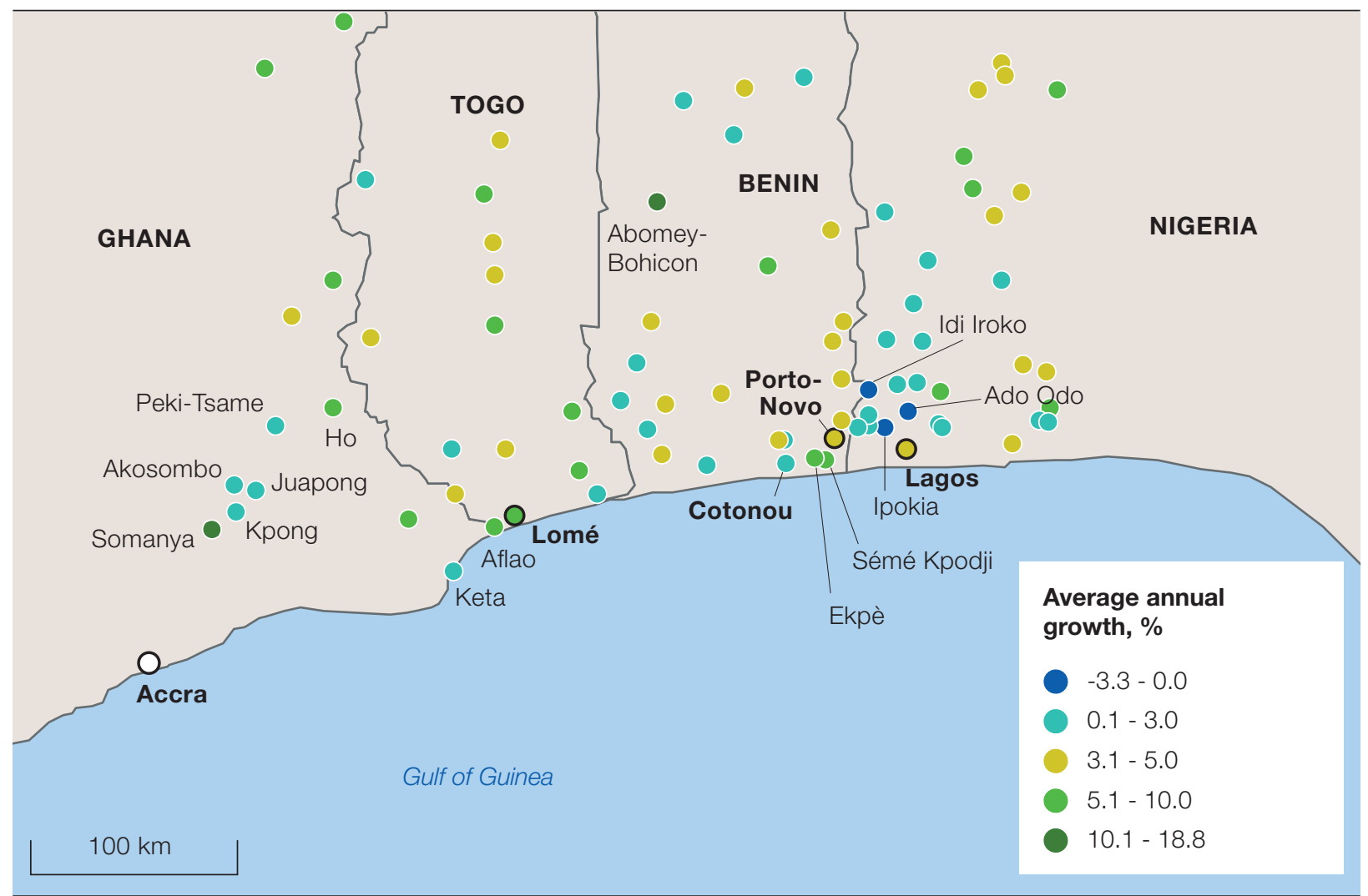

Source: OECD/SWAC 2018

is much higher than that of Keta, a trading town that is now experiencing coastal erosion $(+1.2 \%)$.

The marked infra-regional disparities observed between 2000 and 2010 are still a reality in the current decade (Map 1.7). For the period 2010-20, the strongest urban growth are between Nigeria and Benin along the Gulf of Guinea coast and along Nigeria's western border with Cameroon. Of the 16 cities with average annual growth greater than 10\%, ten are located in Nigeria: Ikot Offiong, Gbenga, Oron, Okpoma, Adikpo, Eket, Idi Emi, Zaki Biam, Ago Egun and Bazza. Nigerian borders are home to 53 of the 125 cities with an average annual growth rate of between 5 and 10\%, as compared with 19 in Chad and 15 in Benin. The strong urban growth observed in the eastern part of Chad is due to the forced migration of refugees from Sudan and the Central African Republic, in addition to demographic growth. Quite moderate growth - less than 2\% per year - was observed throughout the region, from Banjul, Gambia, to the northernmost part of Cameroon, while some cities in western Côte d'Ivoire (Touba, Tabou, Zeaglo and Loboville), in Sierra Leone (Kamakwie and Daru) and in Guinea (Guéckédou) are experiencing negative growth. 


\section{Urban density and growth}

Urban density and its advantages and drawbacks for the process of development has been the subject of vigorous debate in recent decades. As such, West African urban dynamics have often been understood from the perspective of the problems created by density, whether it be traffic congestion, public health, insecurity, pollution or the cost of land. Very few cities in the region are in a position to appropriately respond to the urban, environmental and security challenges that go hand in hand with contemporary demographic growth. They are all faced with rapid increases in population, density and the built environment, without necessarily benefiting from decentralised resources or sufficient political heft at the national level.

The debate on the increased density of African cities has long focused on very large urban centres and their supposedly incontrollable nature. For example, the city of Lagos which is home to 12 million people, has often been presented as an example of urban chaos that fosters crime, traffic congestion, informal urbanisation and pollution. However, recent work has helped call into question this view and identify new urban development strategies capable of accounting for the global forces acting on cities and the local responses to urban growth (Freund, 2007; Locatelli and Nugent, 2009; Myers, 2011).

The polemic against the supposedly inordinate size of West African cities has, among other things, obscured the fact that the region's urban systems include few very large cities, as compared with the international situation. It has also contributed to minimising the social changes in smaller urban centres, which are of particular importance in border regions due to their specialisation in business and trade. Lastly, this interest in urban problems has resulted in overlooking some of the very real advantages associated with the clustering of human activities.

From the perspective of formal and informal businesses, urban density encourages the exchange of information on prices and general changes in the market, makes a diversified labour force more easily accessible and facilitates technology transfers between businesses working in complementary areas of activity. The employees of these businesses also benefit from the possibility of choosing from among a number of businesses and from the availability of certain urban amenities such as the transportation, health and education infrastructure made possible by urban development. These external economies are not exclusive to urban centres in developing countries, where research shows they are important (Glaeser, 2011). They are a factor in all types of cities, including those in West Africa.

Density fosters the tacit sharing of information between businesses and between individuals. Contrary to codified information that may be formalised, 


\section{Map 1.7}

Average annual growth of border agglomerations at $100 \mathrm{~km}$ from a border, 2010-20

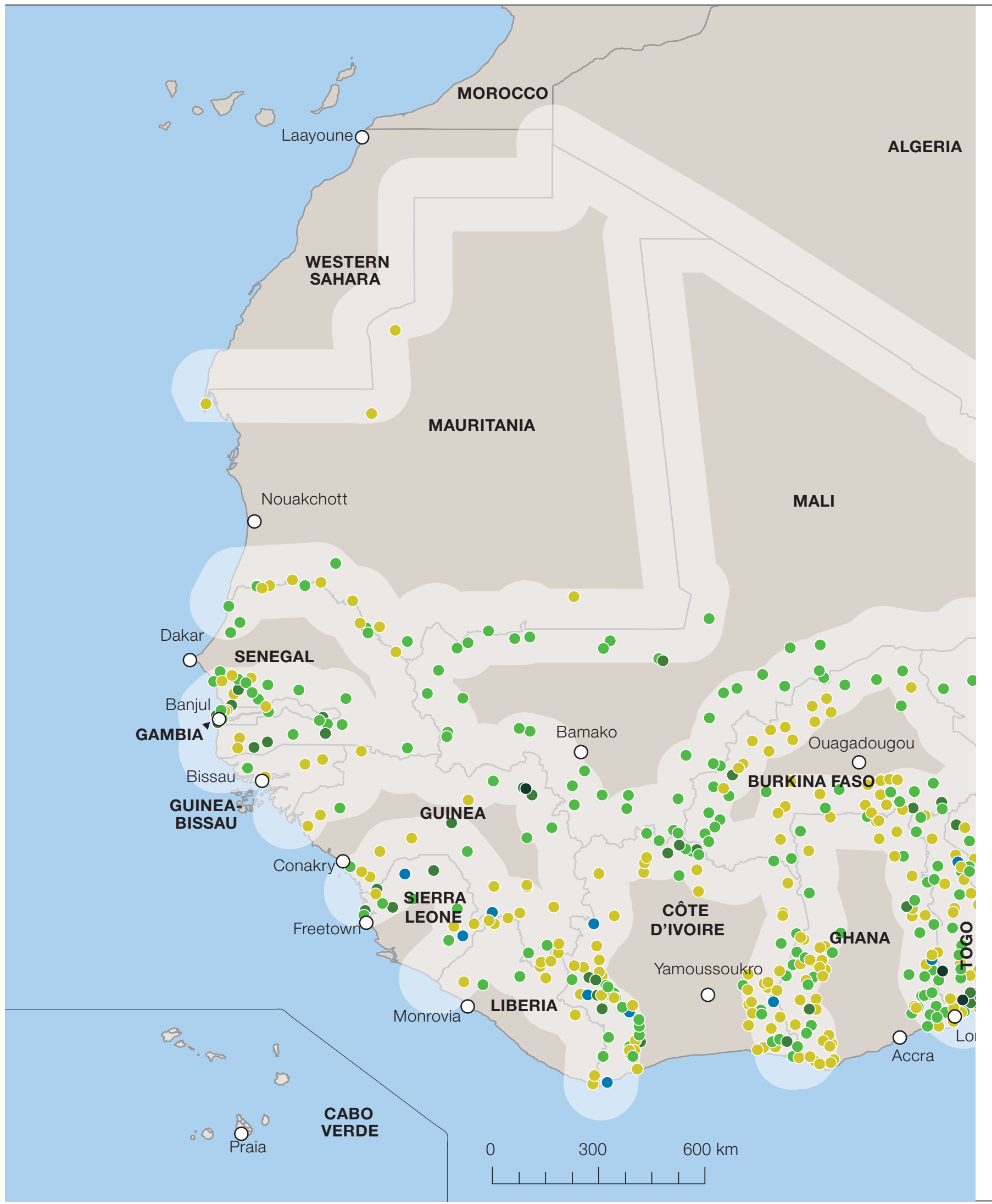




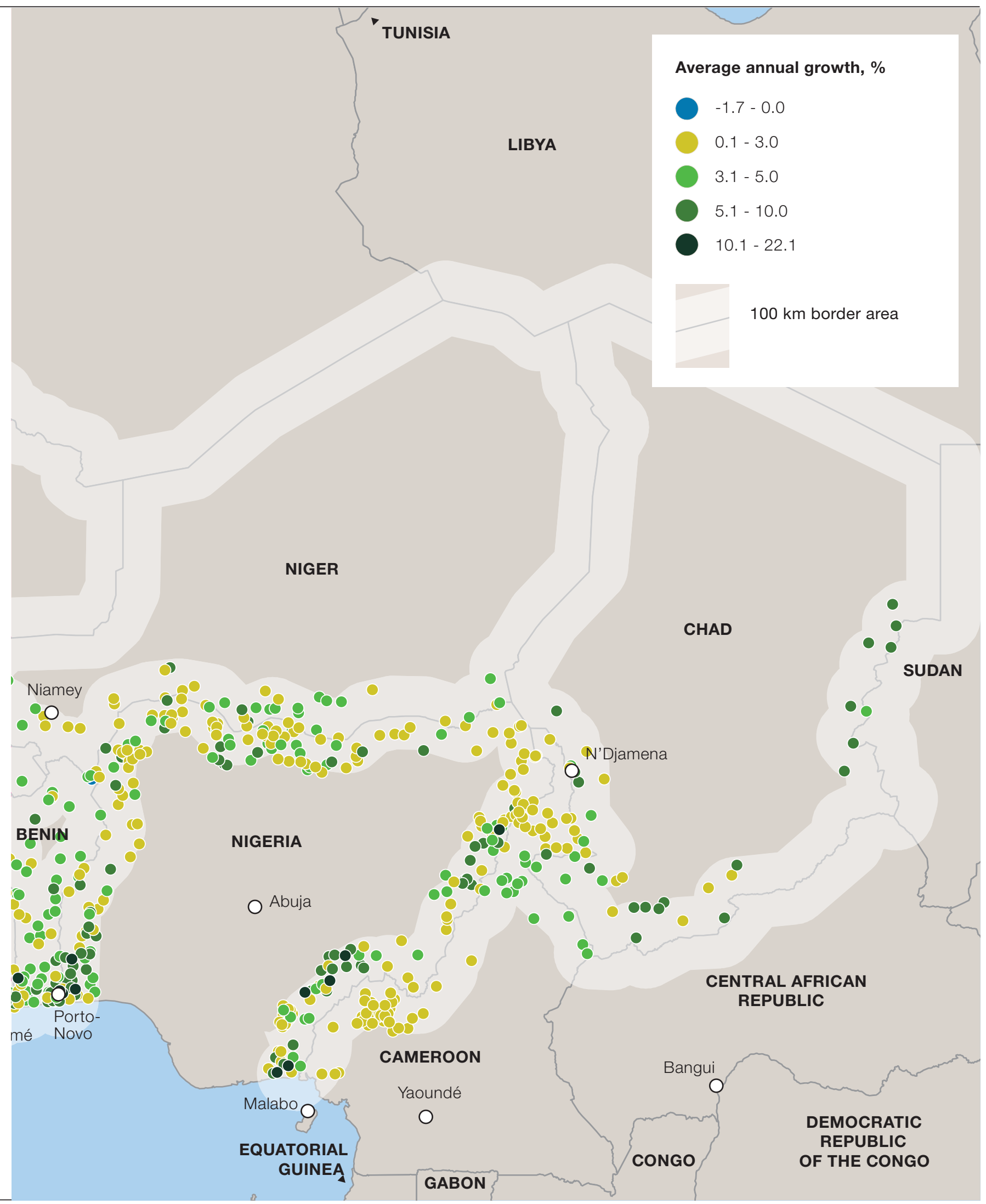


the tacit, face-to-face sharing of information depends to a large degree on the social context in which actors interact. These sets of standards and values are transmitted through socialisation and are especially difficult to duplicate remotely using new communications technology (Storper and Venables, 2004). The regulations governing border crossings in Africa are one example of such non-codified information, which enables traders to negotiate regulatory obstacles and conduct business with representatives of the authorities responsible for border checkpoints (Titeca, 2012; Lamarque, 2014; Niang, 2013; Cantens and Raballand, 2017). The business communities present in border cities enable traders to share their business experiences and develop a set of informal standards that make their activities possible and profitable (Walther, 2015, 2014a; Koné, 2015).

Dense urban environments also encourage social interactions among actors with different skills, languages, nationalities and religious backgrounds. The greater the opportunities to share ideas, values and products that differ from those available locally, the more social actors are encouraged to develop innovative solutions (World Bank, 2009). Innovations emerging from this process are easier to share in an urban setting than in a rural one - where opportunities to meet are fewer - whether it be new agricultural products, dietary behaviours or religious norms. The importance of social mixing in an urban setting is now acknowledged by a growing number of authors who insist on the necessity of looking beyond the "chaos" that characterises many African cities. For example, Lagos is now considered to be especially suitable for individual initiatives as well as architectural creativity (van der Haak, 2005) and literary innovation (Onuzo, 2018) due to the number of people one could potentially meet.

In order for the potential externalities of cities to be transformed into concrete advantages for urban populations, urban growth must be combined with suitable public policies. With the support of public policies suited to urban settings, that growth can be turned into a comparative advantage and a determining factor of social change.

\section{Density decreases with distance from a border}

Urban and national densities are subject to different logics (Figure 1.9). Some countries, such as Mali and Niger, have dense cities, but are relatively sparsely populated as a whole because large sections of them are covered by the Sahara. Conversely, the cities in some small countries like Cabo Verde and Gambia are of average density but heavily populated relative to the territory they occupy (Table 1.3). Nigeria is somewhat of an anomaly in that the population densities of cities and the national territory are high overall. The average density of cities in Chad (12000 people $/ \mathrm{km}^{2}$ ) is due to the presence of a number of refugee camps on the borders of Sudan and the Central African Republic that cover a relatively small area but are occupied by close to 442500 people. 
Figure 1.9

National and urban densities, 2015

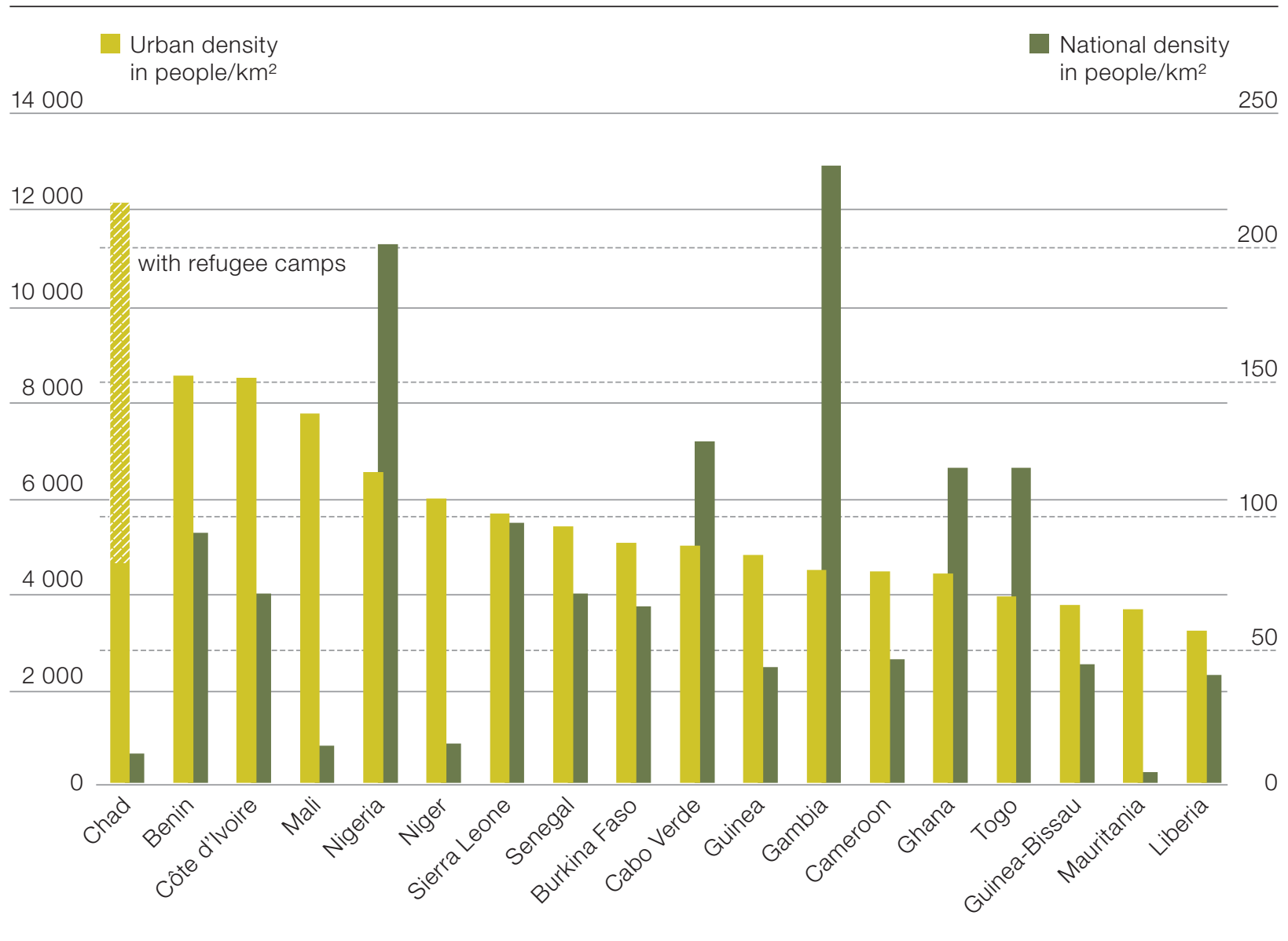

Source: OECD/SWAC 2018

When the refugee camps are excluded from the calculation, Chad has an urban density of 4675 people per square kilometre, slightly higher than that of Cameroon. Elsewhere in the region, the following countries have the highest urban densities: Benin (8674 people/ $\mathrm{km}^{2}$ ), Côte d'Ivoire 8638) and Mali (7 875). Conversely, the cities of Guinea-Bissau, Liberia, Mauritania and Togo appear to be less dense on average, with fewer than 4000 people per square kilometre.

The density of West African cities varies significantly at the national level due to specific modes of land use (Map 1.8). Côte d'Ivoire, which has one of the continent's most recent urban networks (OECD/SWAC, 2018), is a good example of these national dynamics. Cities in the Montagnes district, on the border between Côte d'Ivoire and Liberia, have very high average densities. These urban centres, such as Zouan or Guinglo-Tahouake, are a new agricultural frontier dedicated to cocoa and coffee crops. In addition, cities along Côte d'Ivoire's western border feature higher average densities than cities in Ghana. This is the case because urban sprawl has remained quite low in 
$\underline{\text { Table } 1.3}$

Population and area per country, 2015

\begin{tabular}{|c|c|c|c|c|}
\hline Country & $\begin{array}{r}\text { National } \\
\text { population }\end{array}$ & $\begin{array}{l}\text { National land } \\
\text { area, } \mathrm{km}^{2}\end{array}$ & $\begin{array}{r}\text { Urban } \\
\text { population }\end{array}$ & $\begin{array}{r}\text { Urban land } \\
\text { area, } \mathrm{km}^{2}\end{array}$ \\
\hline Benin & 10749468 & 112622 & 5072168 & 1185 \\
\hline Burkina Faso & 18450494 & 274366 & 5276926 & 1187 \\
\hline Cabo Verde & 524833 & 4033 & 263913 & 49 \\
\hline Cameroon & 22179707 & 468315 & 12754444 & 4071 \\
\hline Côte d'Ivoire & 23300000 & 322462 & 11489818 & 1478 \\
\hline Gambia & 2023790 & 8613 & 1127487 & 285 \\
\hline Ghana & 27403036 & 227533 & 14247403 & 3649 \\
\hline Guinea & 10923758 & 245790 & 4044553 & 806 \\
\hline Guinea-Bissau & 1530637 & 34107 & 525458 & 106 \\
\hline Liberia & 4045171 & 99025 & 1715625 & 425 \\
\hline Mali & 17819002 & 1242248 & 5697331 & 1124 \\
\hline Mauritania & 4034103 & 1035000 & 1713049 & 389 \\
\hline Niger & 18850739 & 1271947 & 3270216 & 550 \\
\hline Nigeria & 186939800 & 913475 & 97795768 & 19723 \\
\hline Senegal & 14143151 & 196712 & 7156859 & 959 \\
\hline Sierra Leone & 7092113 & 71740 & 2592400 & 448 \\
\hline Chad & 13670084 & 1274413 & 3899403 & 776 \\
\hline Togo & 6835000 & 56785 & 3420177 & 974 \\
\hline Total & 390514884 & 7859185 & 182062998 & 38183 \\
\hline
\end{tabular}

Source: OECD/SWAC 2018

the 2010s due to the political instability that has slowed urban development (OECD/SWAC, 2018). Elsewhere in the region, Nigerian cities generally have higher densities than those in Cameroon, but equal to those in Niger, from the Lake Chad basin to the Dendi region. The cities in northern Burkina Faso are particular in that they have relatively low densities as compared with cities along Mali's borders.

Of the cities with more than one million inhabitants in 2015, Abidjan, Dakar, Douala, Kano, Lagos and Yaoundé have extraordinary high densities as 
Figure 1.10

Density and population of million-inhabitant cities, 2015

Urban density

in people $/ \mathrm{km}^{2}$

Population

in millions

16000

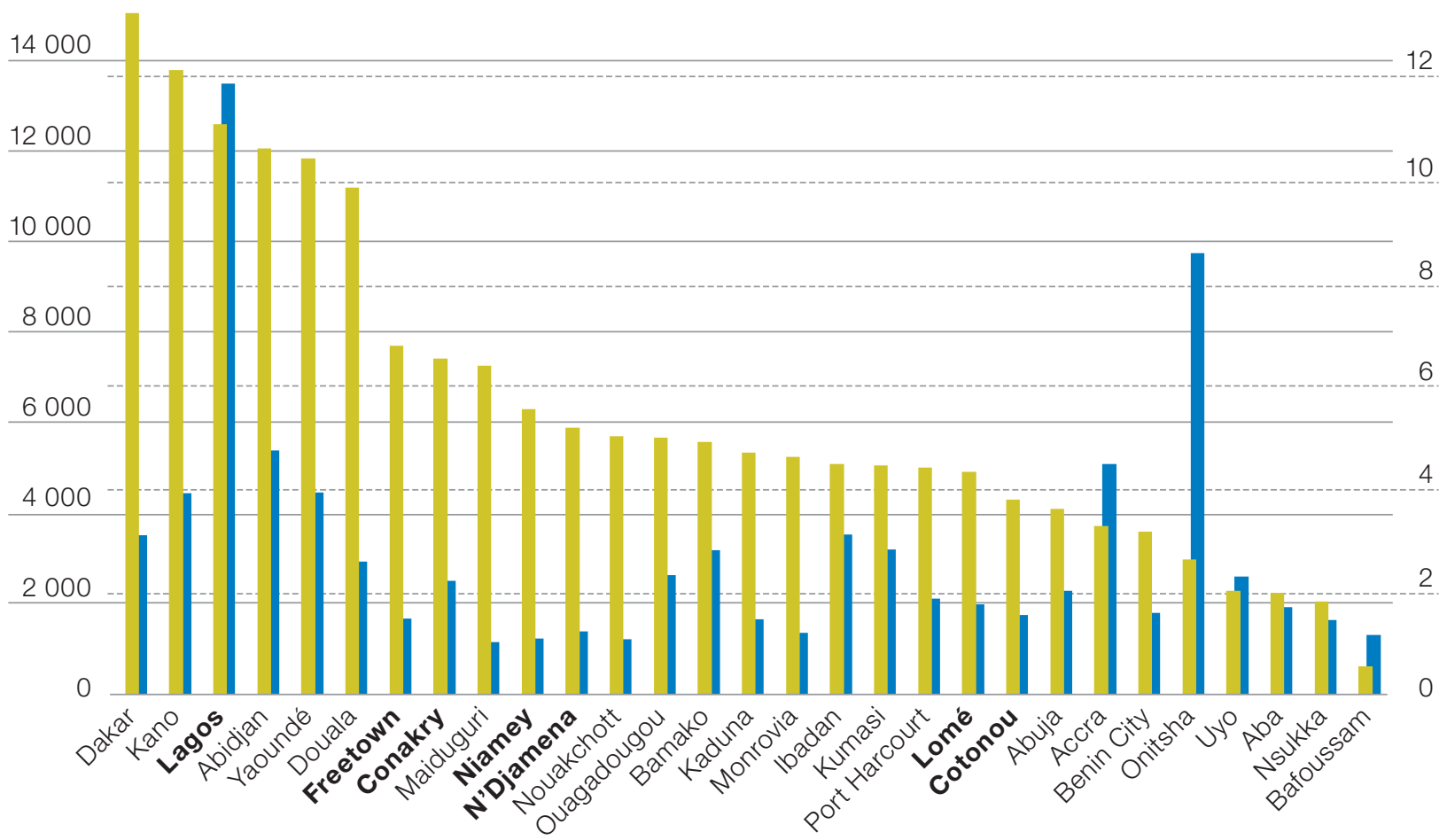

Note: Cities within $100 \mathrm{~km}$ of a border are shown in bold. Source: OECD/SWAC 2018

compared with the international level (Figure 1.10). With over 15000 inhabitants per square kilometre, the density of the capital city of Senegal, squeezed into the Cape Verde peninsula, is similar to that of Casablanca, Morocco, while that of Lagos (12600 people $/ \mathrm{km}^{2}$ ) is comparable to that of Karachi, Pakistan.

A second group of cities have densities of between 4000 and 8000 people per square kilometre, of which Freetown, Conakry, Niamey and N'Djamena are located less than 100 kilometres from a land border. At 6300 people per square kilometre, Niamey's density is comparable to that of Rio de Janeiro, Brazil, which is quite remarkable given that most Nigerien residences are one-storey family homes (concessions). In these urban environments, high densities are due to the very high average size of families, rather than the existence of multi-storey buildings.

Lastly, densities lower than 4000 people per square kilometre were observed in a number of cities along the Gulf of Guinea, in southern Nigeria (Benin City, Onitsha, Uyo, Aba and Nsukka), Ghana (Accra) and in the Bamileke 
Map 1.8

Density of border agglomerations, 2015

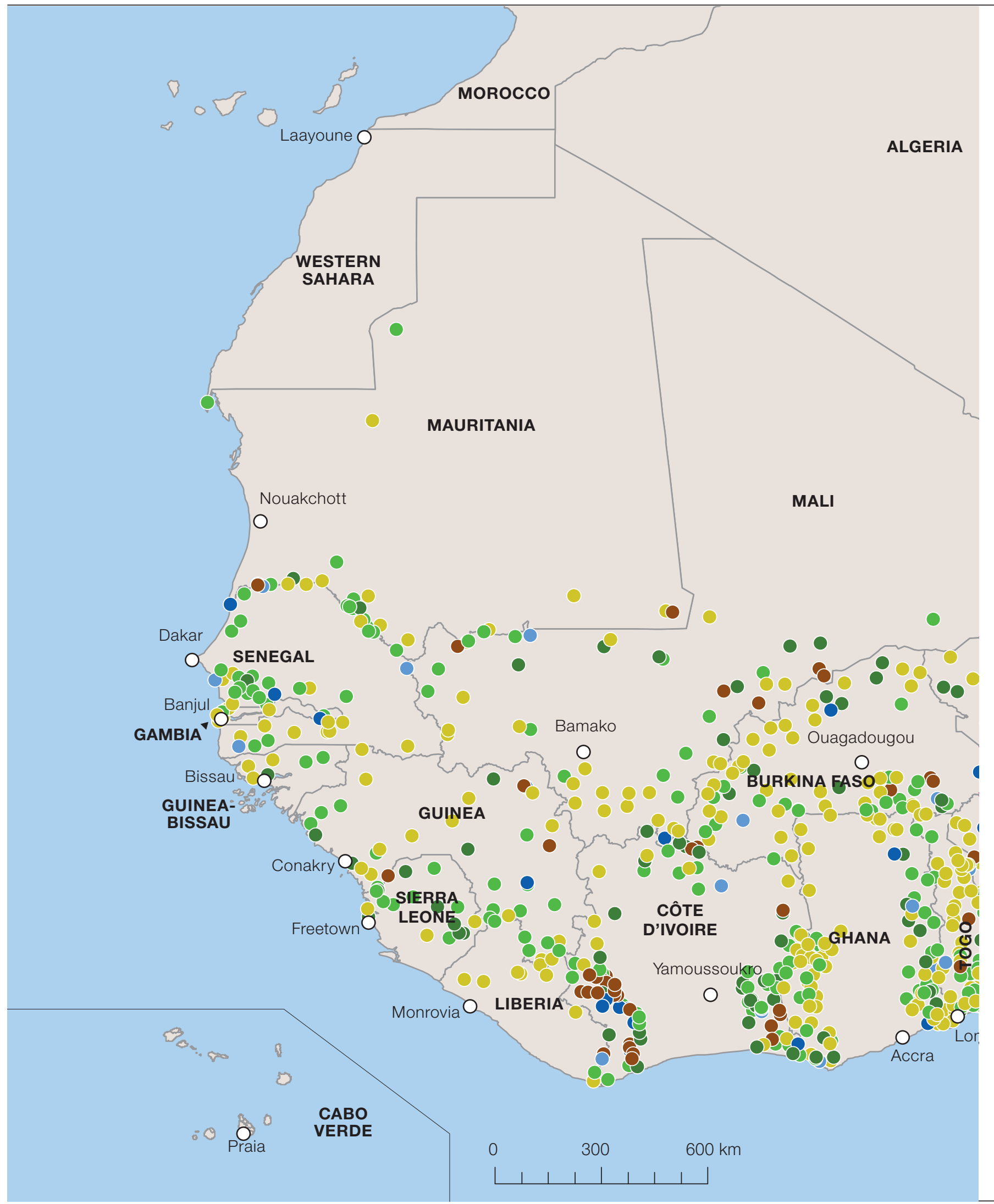




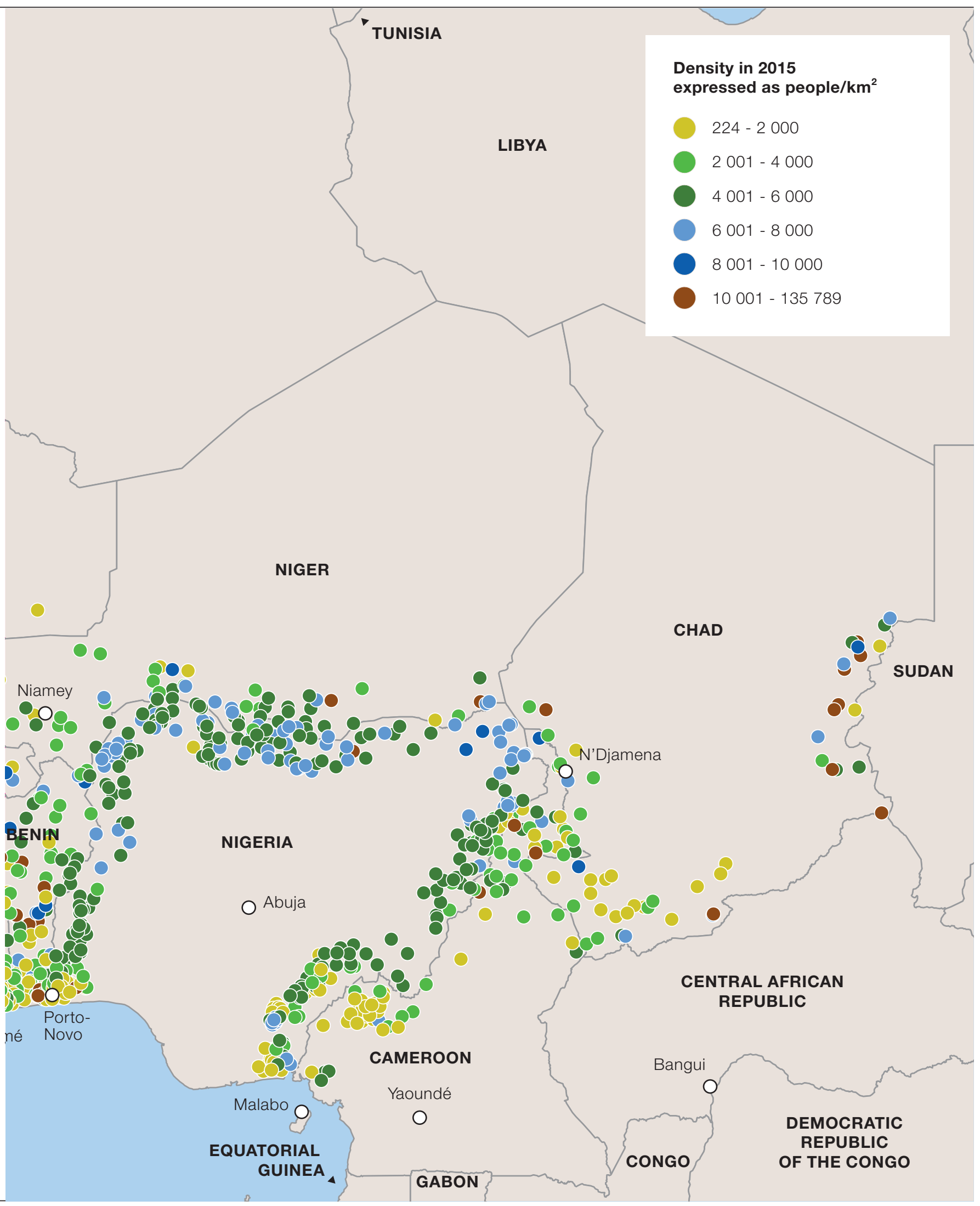


region of Cameroon (Bafoussam). The density of Onitsah (3000 people/ $\mathrm{km}^{2}$ ), the second most heavily populated city in the region, is similar to that of Moscow, Russia. Land use in the Ibo capital, decentralised and sparsely populated, differs from that of the high density in Kano, in the north

Table 1.4

Urban population based on distance from a border, 2015

\begin{tabular}{|c|c|c|c|c|}
\hline & \multicolumn{4}{|c|}{ Distance from a border } \\
\hline $\begin{array}{l}\text { Density in } \\
\text { people/km² }\end{array}$ & $20 \mathrm{~km}$ & $50 \mathrm{~km}$ & $100 \mathrm{~km}$ & All cities \\
\hline Average & 7405 & 6841 & 6807 & 6562 \\
\hline Median & 5338 & 5199 & 5500 & 6122 \\
\hline
\end{tabular}

Source: OECD/SWAC 2018
(13800 people/ $\mathrm{km}^{2}$ ), and Lagos.

Generally speaking, the density of border cities is higher than that of the average urban centre in the region and decreases with distance from a border (Table 1.4). It varies from an average of 7400 people per square kilometre at 20 kilometres from a border, to 6800 at 100 kilometres away, which again highlights the demographic specificity of border cities. As with urban growth, the fact that the median is lower than the observed average indicates that some cities have a much higher density than others. Other than the refugee camps previously mentioned, urban densities are exceptionally high in some gold mining sites such as Massiogo, Mali, that are likely to experience quite rapid changes in population. 

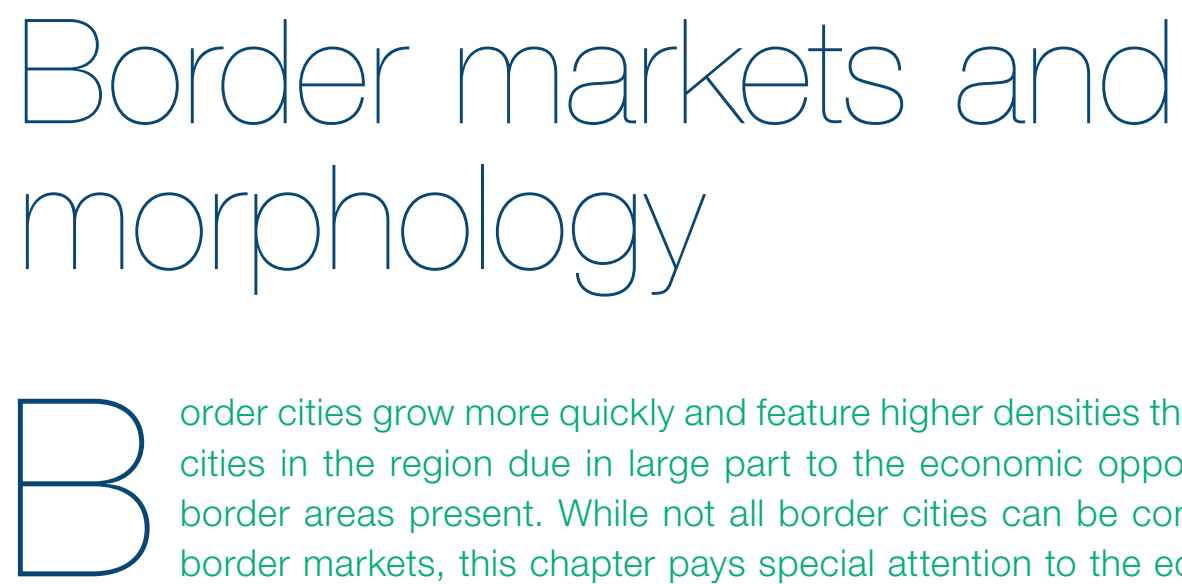

order cities grow more quickly and feature higher densities than other cities in the region due in large part to the economic opportunities border areas present. While not all border cities can be considered border markets, this chapter pays special attention to the economic foundations of the demographic development of cities located near a border. Finally, the urban environment is variously affected by the existence of borders as shown by morphological characteristics.

\section{Why do border markets flourish?}

Border markets are different in important respects from other markets ${ }^{1}$. While regional and national markets draw their wealth from their hinterlands, border markets thrive at the point of convergence of transnational networks. Whereas most markets evolve slowly, border markets experience sudden booms or declines due to variations in price differentials, exchange rates between currencies, taxes between countries, and bans on imports and exports. Unlike other markets that primarily owe their importance to the size and qualifications of their labour pool, border markets are dependent on the business opportunities offered by their peripheral location, which makes them paradoxically central at the regional level (Zeller, 2015).

The mere presence of a border and a city is not sufficient to create the conditions of bustling cross-border activity. Many border regions experience only a little cross-border trade, and many cities actually turn their back to the border rather than transforming these into economic hotspots. Previous OECD/ SWAC studies $(2017,2014)$ indicate that the 135 border markets identified from Senegal to Chad in the mid-2010s are unequally distributed (Map 2.1). Some regions have clusters of markets, often organised as twin cities, while large stretches of border have none at all. Dense clusters of border markets contribute to forming functional border regions where social and economic interaction is potentially intense.

1 This section is based on a previously published article (Walther 2014) reproduced here with permission from the journal. 


\section{Map 2.1}

West African border markets

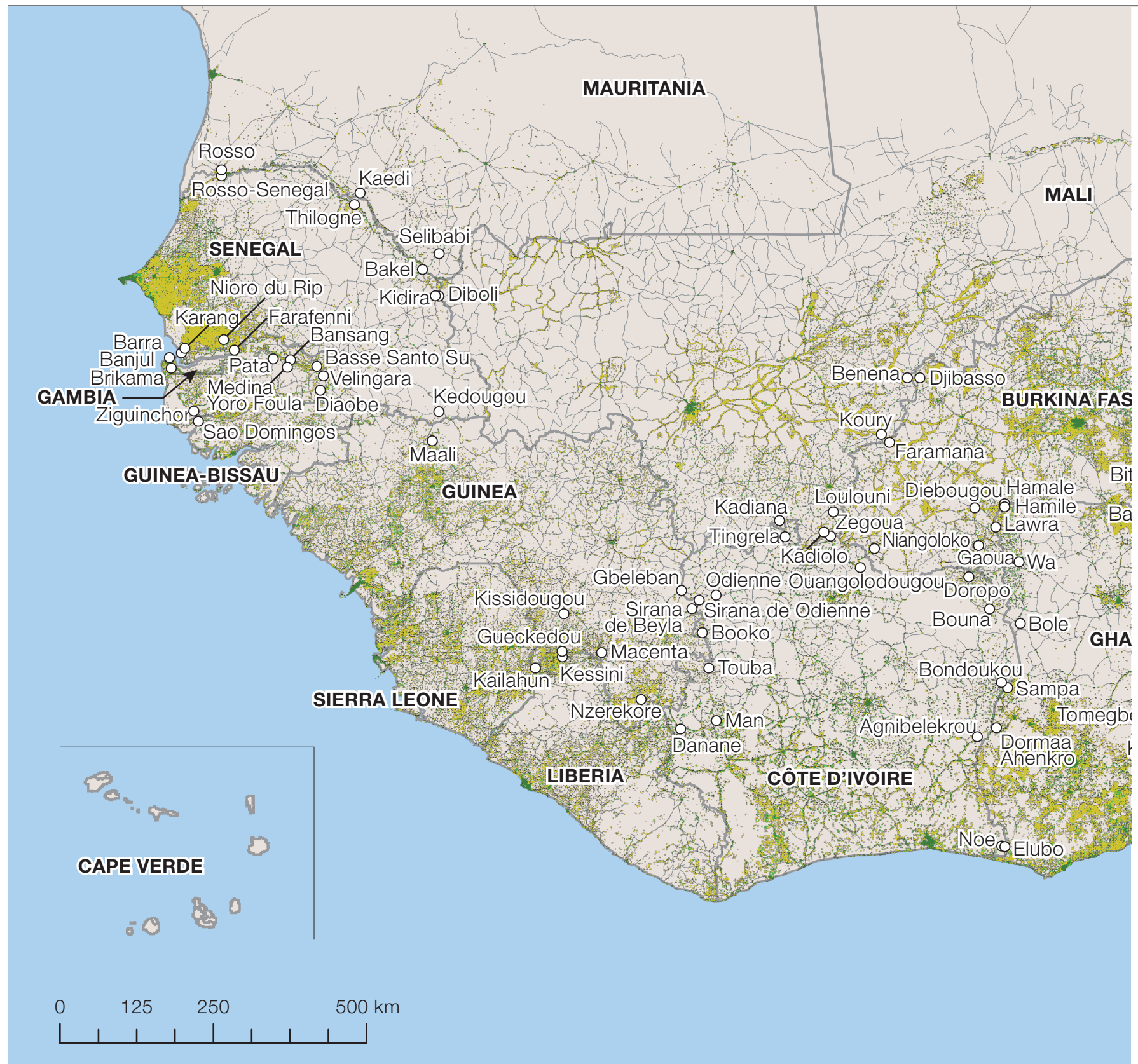

Source: OECD/SWAC 2017

In the west, the densest markets are in southern Senegambia (the Ziguinchor, Farafenni and Diaobé markets) and along the Senegal River (the Rosso, Kaédi and Bakel markets). The borders of Côte d'Ivoire also represent a focal point for regional integration, comprising three submarket clusters: between Kissidougou, Nzérékoré, Man and Odienné in the west; between Kadiolo, Kadiana and Zégoua in the north; and between Wa and Agnibélékrou in the east. The central part of the region contains three clusters of markets that are relatively separate from others: northern Togo, with the markets 




of Bittou, Dapaong and Cinkassé; the region of Borgou centered around the markets of Nikki and Okuta; and the trinational region of Dendi with the markets of Gaya, Malanville and Kamba. Further east, the two biggest market concentrations are in northern Nigeria and around Lake Chad. The former, centred around northern Hausaland, straddles the border over a wide area of the Niger-Nigeria border between Birni N'Konni and Maigatari. The latter is also vast, covering the far east of Niger, Lake Chad and northern Cameroon down to Touroua. Conversely, border markets are 
rare in Fouta Djallon, Liptako-Gourma, between Liberia and Côte d'Ivoire, and between Niger and Mali.

So why do some border cities turn into dynamic border markets while others do not? The following sections explore three factors that impact the economic development of border markets: the presence of a skilled community of traders that can successfully exploit border differentials, the combination of trading and productive activities that rely on market and transport infrastructure, and the relative porosity of borders, which provides business opportunities.

\section{Trade communities}

The success of border markets is primarily linked to the people involved in trade. Without an innovative community of traders involved in transnational business networks, border towns and cities can hardly pretend to be border markets. By exploiting the various differentials that characterise border regions, including food price differentials (Map 2.2), these entrepreneurs profit from connecting different nationally-organised markets (Walther, 2015).

Throughout history, these business communities have been crucial to the prosperity of market places. Many markets that flourished before colonisation have vanished or dramatically declined in the 20th century, such as Salaga, Ghana; or Kong, Côte d'Ivoire; because they no longer served as crossroads along regional trade routes or because their political support disappeared. In some places, such as Gaya, Niger, the memory of a past history of longdistance trade has completely disappeared from migration-and-settlement narratives, despite the fact that the city was located on one of the main trade routes developed between Hausaland and Asante in the 19th century (Lovejoy, 1986). Inversely, some of the more dynamic contemporary border markets are products of colonialism (Nugent, 2002), strategically placed along the new transportation routes created by colonial powers.

\section{Circulation and production}

Another important factor in the development of border markets is their ability to combine trading and production activities. As market places, African border markets are intimately linked to the trade flows in raw materials, commodities and services that connect the globalised world. Border markets can therefore be seen as places of convergence for the transnational movements of goods and people (Dobler, 2016). However, border markets are more than places of flows; they also play a crucial regional role in the organisation of agricultural activities. In Africa, border markets combine, on the same site, a variety of goods that transit only briefly through the market, such as second-hand cars, cigarettes or fuel, and, simultaneously, agricultural products, such as onions or cereals, for which the border market serves as a place of storage before being distributed regionally. In other words, it is in border markets that the two different spatial strategies of transnational circulation and regional production converge (Walther, 2012). 
The presence of a reliable market and transport infrastructure is crucial for trade communities and producers because it allows the combination of trading and production activities to benefit the regional economy. Today, a number of private and public initiatives are being developed to upgrade road and rail infrastructure along designated transport corridors and facilitate trade across the region through one-stop border posts (see West African Paper no. 23).

\section{Porous borders}

Another factor that can determine the success of border markets is the relative porosity of borders. The degree of openness of the border greatly varies between cases and generates specific flows of goods and people. Borders that are officially closed to a number of products to protect national production, but functionally open to informal flows thanks to the collusion between traders and state authorities, offer a stimulating environment for cross-border trade. This phenomenon is particularly visible on the Nigerian borders, where the state has resisted the harmonisation of external tariffs and the removal of barriers to trade promoted by the Economic Community of West African States (ECOWAS) (Golub, 2012). As a result, while most Francophone countries in the region have embraced free-trade policies, Nigeria continues to prohibit the import of several goods, such as second-hand cars (Beuving, 2015) or clothes (Brooks and Simon, 2012), whose illegal trade has considerably enriched long-distance traders.

Markets on both sides of the Niger-Nigeria border, for example, have flourished from the trade of various commodities and agricultural products, which the Nigerian economy could no longer produce, that were heavily subsidised, or that could be purchased for a lower price on global markets (Map 2.2) (Hoffmann and Melly, 2018). Import and export bans on a range of staple food grains and manufactured products further increased re-exports of goods from world markets that formally arrived in Benin, transited trough Niger, and entered the Nigerian market illegally.

\section{Urban morphology}

Borders effect urban environments in a variety of ways. As such, morphology reflects the different land use arrangements resulting from the history of human settlement, the various functions of cities over time and national territorial development strategies. The current location and morphology of border cities has changed dramatically since the end of the 19th century (Soi and Nugent, 2017). In the first place, colonisation encouraged a number of human establishments to move to a location nearer the new road and rail infrastructure (Njoh, 2006) or to relocate to various colonial borders to take advantage of legislative and pricing differences or to avoid taxation (Box 2.1). These relocations were particularly numerous on the borders separating British and French colonies, as was the case for the border cities around 


\section{Map 2.2}

Food price differentials

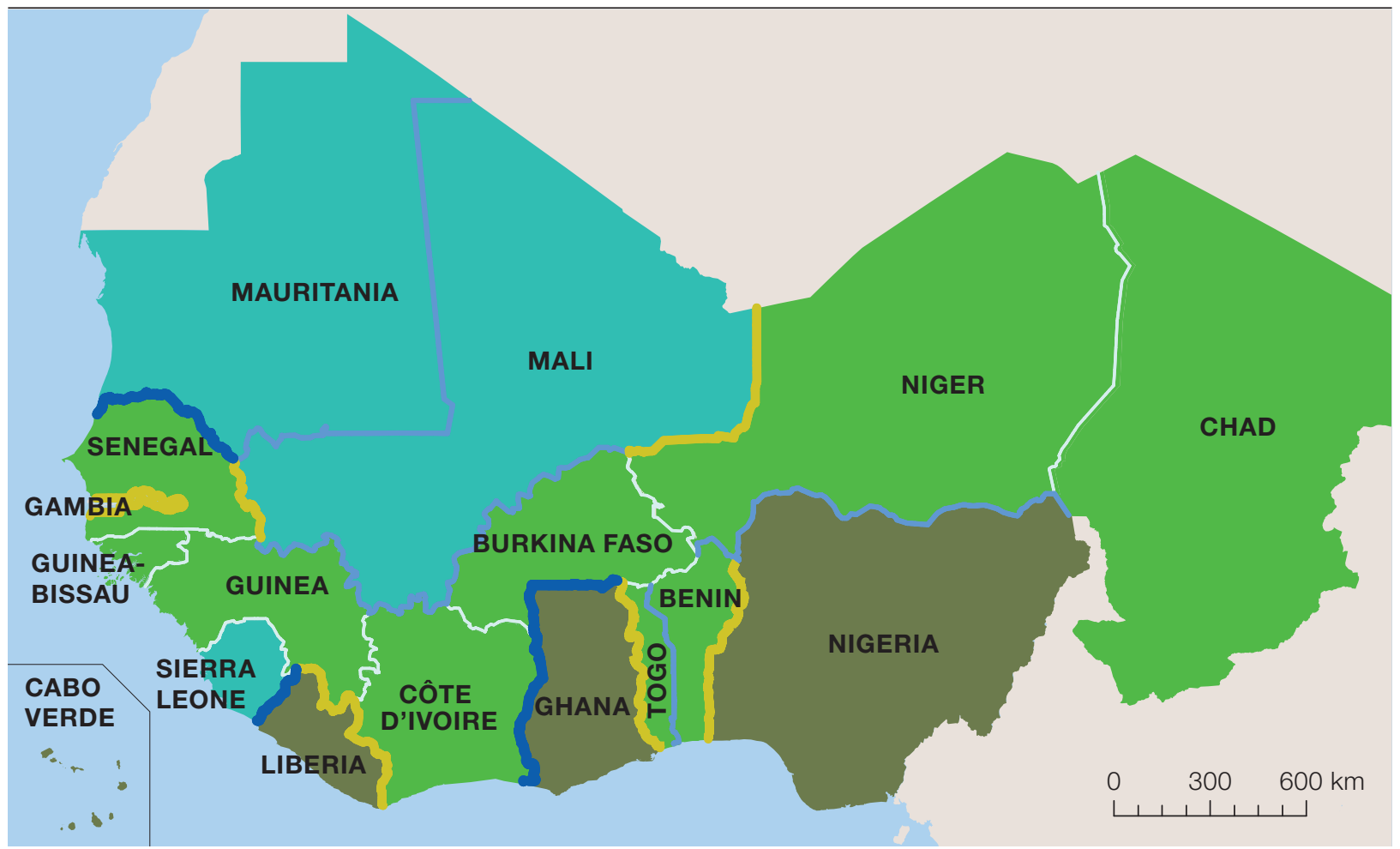

Food price levels in West African countries (relative to the regional average)

Low $(<-8 \%)$ Medium $(-8-+8 \%)$

High (> +8\%)

Food price border differentials between West African countries, land borders (relative to the regional average)

$\operatorname{Low}(<6 \%) \longrightarrow$ Medium $(6-17 \%) \longrightarrow$ High $(17-23 \%)$

Very high (> 23\%)

Source: Allen 2017

Nigeria and Ghana (Miles, 1994 and Nugent, 2002). Today's "twin-cities" often create the illusion of having been divided as a result of colonisation, when in reality, they are the result of opportunistic relocation.

The impetus imparted by cross-border trade during the colonial period continued after independence. The liberalisation of regional trade in the 1980s further fostered these dynamics (Walther, 2009). Some nation-states located on the interface of several customs and monetary systems, such as Benin and Gambia, then specialised in re-exporting agricultural and manufactured products from the global markets to neighbouring countries that had imposed import restrictions. Border cities profited from these national strategies and then experienced spectacular development. Located on one of the main trade corridors for re-exporting used textiles and vehicles, the population of Gaya, a small Nigerien city, jumped from 8000 to 45000 people between 1985 and 2015 (Walther, 2015). 
Box 2.1

Spatial restructuring in Sierra Leone-Guinea

In precolonial times, trade routes were known to be mobile, as were human settlements. In the Sierra LeoneGuinea region, for example, trade corridors connecting Futa Jallon to the Atlantic Ocean and those along the coast of the Gulf of Guinea were composed of several routes. Smaller routes crossed corridors, creating a grid. Resources of trade were diverted by traders to develop the centrality of their towns, by securing trade routes, hosting traveling traders, building facilities, and creating a dense network of clients (Howard, 2014).

The construction of railway lines by the colonial powers considerably perturbed those trade corridors, as some markets lost their centrality. On both sides of the colonial border, rail systems were developed to extract crops and channel imports to Conakry in French Guinée and Freetown in Sierra Leone. Both colonial infrastructures remained separated. As a result, the dendritic system imposed by colonisation and oriented towards regional centres progressively replaced the grid upon which traders had relied until the 1890s.
Some African traders successfully adapted to the new spatial order imposed by the French and the British. African kola traders, for example, quickly realised the advantages of using steam ships to develop new networks to other colonies and of relying on telegraph to follow prices and deliveries. A number of "smugglers", as the colonial powers started to call them, also crossed the newly established borders in search of higher prices for local products and to respond to the increasing demand for imports from the rest of the world. Cattle traders also prospered after having moved to new rail centres. Other African traders, however, could not compete with European firms, especially long-distance traders, whose social networks had been affected by the restructuring of the trade route, as caravans sponsored by African states were replaced by colonial railways.

Source: Walther 2014b

The mostly spontaneous growth of border cities poses numerous development challenges for new regional and local governments. As decentralised financing has not yet been perfected, public authorities do not have the financial means to respond to new issues arising from urban sprawl. Consequently, border cities often develop in an informal and unplanned manner, which hinders their economic potential. New residential neighbourhoods do not have sufficient services and infrastructure, while the city cores where most commercial activity is concentrated, are congested and outdated. These conditions, which apply to all cities in the region, are worse in border areas due to the absence of urban plans shared with the other side of the border.

Of the 319 cities located less than 20 kilometres from a land border in 2015, 27 fall into the category of major cross-border agglomerations (Map 2.3). They account for more than 3.7 million inhabitants, or 3\% of the total urban population living at that distance from a border. Nine of the 27 cities are located on the borders of Nigeria, six on Benin's borders and five on Ghana's borders. Four of them are located in the Senegal River valley. 


\section{Map 2.3}

Major cross-border agglomerations, by type, 2015

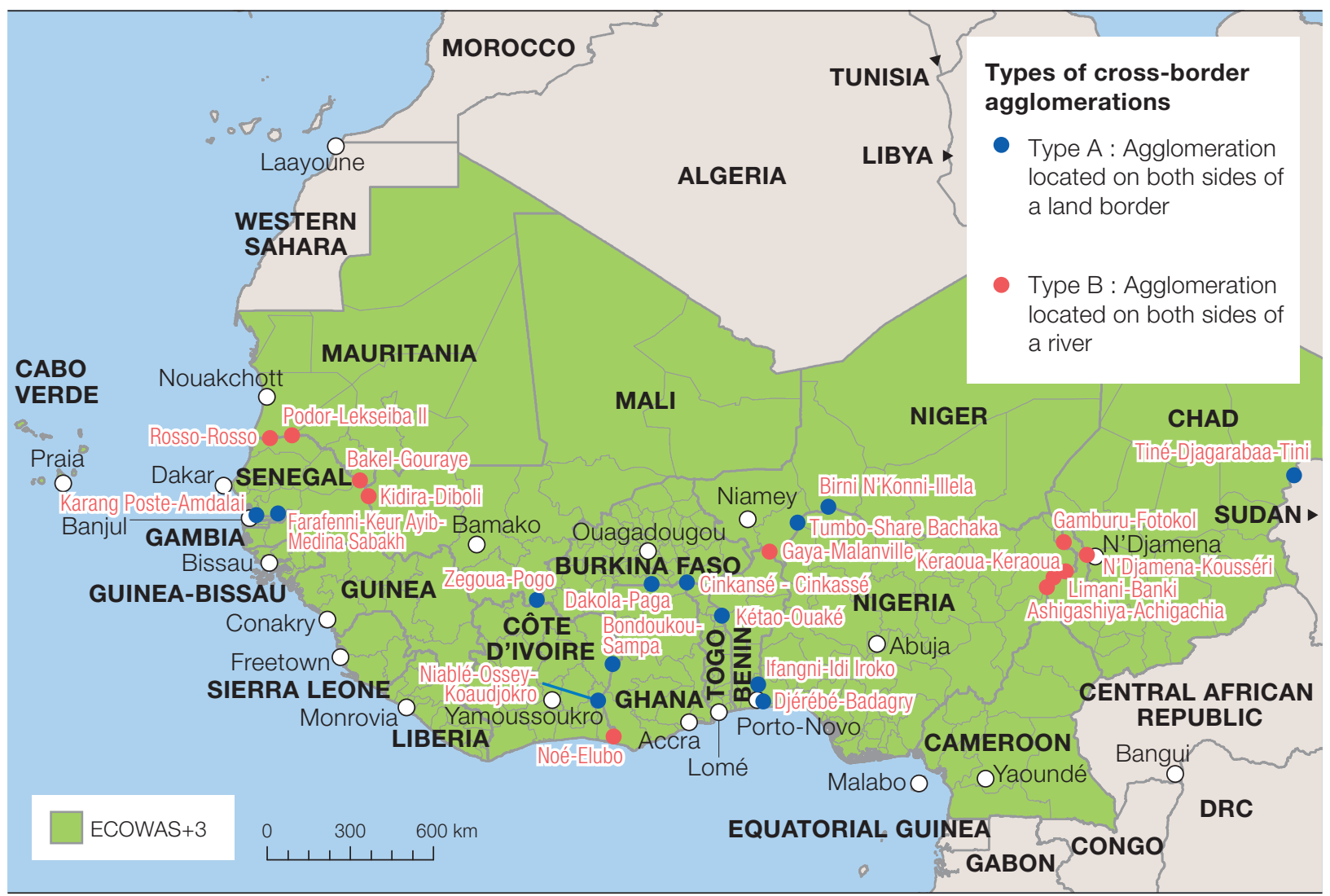

Source: Mission Opérationnelle Transfrontalière (MOT)

These agglomerations can be classified into one of two categories: those located on either side of a land border (16 agglomerations), and those situated on either side of a river (11 agglomerations) (Table 2.1). Three of the cities that share a land border are also located on a small section of the Guinea coast: Lomé-Aflao between Togo and Ghana, Sémé-Badagry between Benin and Nigeria and Aného-Hilacondji between Togo and Benin.

The urban centres separated by a land border are most often established along a main road or rail route. Cinkansé, an urban centre between Togo and Burkina Faso, with a population of over 53000 people in 2015, is a good example of this type of urban development featuring a continuous built environment and origins tied to cross-border trade in contraband. The existence of agglomerations separated by a river is due to the fact that colonial powers often sought to locate urban centres near a waterway, which was the only means of transport before road and rail infrastructure was built; they also sought to use waterways to delineate the internal and external borders of colonies (Soi and Nugent, 2017). Dugout canoes were used to cross rivers in the smallest centres; ferries and bridges were also used. Malanville-Gaya, located on the Niger River between Benin and Niger, is a representative 
Table 2.1

Population of major cross-border agglomerations, by type, 2015

\begin{tabular}{|c|c|c|}
\hline Agglomerations & Population in 2015 & Type \\
\hline N'Djamena - Kousséri (TCD-CMR) & 1311294 & B \\
\hline Lomé - Aflao (TGO-GHA) & 998379 & $A^{*}$ \\
\hline Sémé-Kpodji - Badagry (BEN-NGA) & 266300 & $A^{*}$ \\
\hline Djérégbé - Badagry (BEN-NGA) & 252017 & A \\
\hline Gaya - Malanville (NER-BEN) & 111174 & B \\
\hline Birni N'Konni - Illela (NER-NGA) & 108714 & A \\
\hline Bondoukou - Sampa (CIV-GHA) & 108421 & A \\
\hline Gamburu - Fotokol (NGA-CMR) & 97670 & B \\
\hline Cinkansé - Cinkassé (BFA-TGO) & 53093 & A \\
\hline Rosso - Rosso (SEN-MRT) & 50940 & B \\
\hline Idi Iroko - Ifangni (NGA-BEN) & 44149 & A \\
\hline Farafenni-Keur Ayib - Medina Sabakh (GMB-SEN) & 37257 & A \\
\hline Kétao - Ouaké (TGO-BEN) & 36290 & A \\
\hline Limani/Bula Chirabe - Banki (CMR-NGA) & 35031 & B \\
\hline Aného - Hilacondji (Grand Popo) (TGO-BEN) & 33101 & $A^{*}$ \\
\hline Bakel - Gouraye (SEN-MRT) & 32028 & B \\
\hline Elubo - Noé (GHA-CIV) & 27440 & B \\
\hline Zégoua - Pogo (MLI-CIV) & 25139 & A \\
\hline Karang Poste - Amdalai (SEN-GMB) & 18305 & A \\
\hline Niable - Ossey-Koaudjokro (CIV-GHA) & 16190 & $A$ \\
\hline Tiné - Djagaraba-Tini (TCD-SDN) & 16138 & A \\
\hline Ashigashiya - Achigachia (NGA-CMR) & 13036 & B \\
\hline Keraoua - Keraoua (NGA-CMR) & 12470 & B \\
\hline Podor - Lekseiba II (SEN-MRT) & 12153 & B \\
\hline Paga - Dakola (GHA-BFA) & 11034 & A \\
\hline Tumbo - Share Bachaka (NGA-NER) & 10828 & A \\
\hline Kidira - Diboli (SEN-MLI) & 10538 & B \\
\hline Total & 3749129 & \\
\hline
\end{tabular}

Note: An asterisk indicates an urban centre located on a coastline.

Source: OECD/SWAC 2018 


\section{Map 2.4}

The Gaya-Malanville cross-border agglomeration (Niger-Benin)

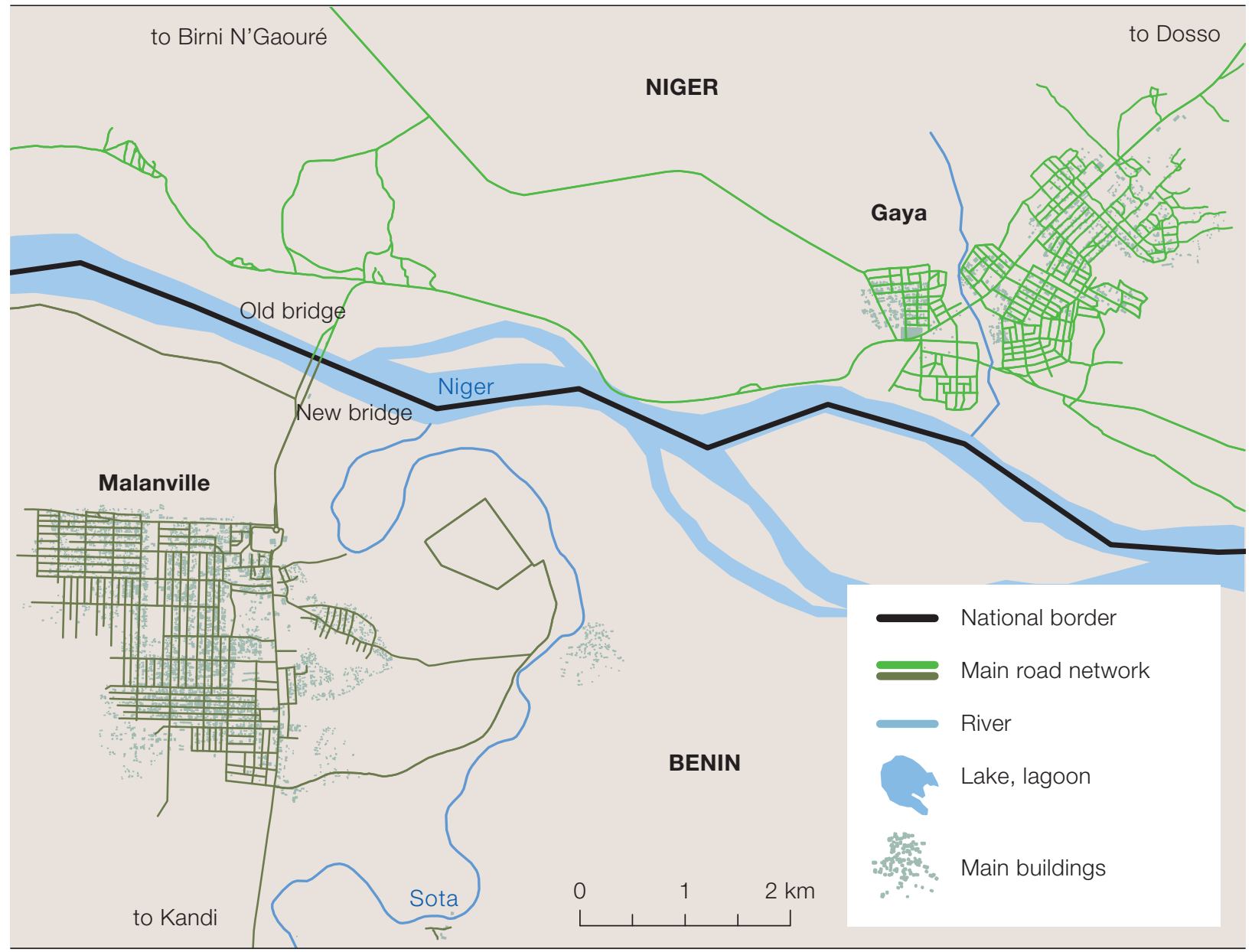

Source: OpenStreetMap 2018

example of these urban centres that are well integrated economically despite the necessity of crossing the river (Sougué, 2016). (Map 2.4).

Crossing the Niger River is of particular historical significance for the local populations. According to Gaya's origin myth, the founding hero, Kokoa Monzon, crossed the Niger River on a magic snake to escape from the Borgu horsemen (Walther, 2012). The two cities were connected by ferry until the first concrete bridge was built as part of France's Operation Hirondelle in 1953 in order to ship peanut products to Niger via the Gulf of Guinea, thereby avoiding Anglophone Nigeria (Bach, 2016). A new and larger bridge was constructed more recently and on which the police and customs services of both counties were set up before their supposed move to the new joint check point built in Malanville (see West African Paper no. 23).

Regardless of their morphological type, cross-border urban centres form urban units in which each side of the border is highly dependent on the other. 
The rapid development of one side of the border often corresponds to a major change in regulations or circumstances on the other side. Over time, these interrelations may result in a certain degree of specialisation. As such, the development of the used textiles trade in Gaya, Niger, is due in part to new regulatory constraints imposed on traders in Malanville, who then moved their business to the other side of the Niger River. Having shifted away from the used garment trade, Malanville has since specialised in the trade of regional agricultural products including onions, rice and maize.

One special case involves cross-border agglomerations in which a capital city is located across from another urban centre. These agglomerations are particular in that they link together cities of very unequal size and varied functions. While the capital cities can develop without depending exclusively on cross-border trade, the smaller centres near them owe their existence to the relationships they are able to establish on the other side of the border. There are three cases of this type of agglomeration in West and Central Africa: Lomé-Aflao between Togo and Ghana; N’Djaména-Kousséri between Chad and Cameroon; and Bangui-Zongo between the Central African Republic and the Democratic Republic of Congo.

The map of the road network along the Togo-Ghana border clearly shows the marked discontinuity in urban planning. While the Lomé/Aflao built environment is continuous along the coast, the Togolese section has a much denser and more structured road system than does the section within Ghana, where many of the transportation routes are not paved and settlement is much more informal (Map 2.5). The territorial discontinuity is more marked north of the coastal lagoon, where high density and wide avenues on the Lomé side contrast with the collection of small towns separated by small agricultural parcels on the other side of the border. This situation has its roots in a historical context dating back to the end of the 19th century. Lomé was originally built by the Germans based on a rigid urban grid which separated the colonial administrative sector from the other previously built commercial districts (Soi and Nugent, 2017; Gervais-Lambony and Nyassogbo, 2007). After the Second World War, the French colonial administration expanded the original grid. Urban growth on the Ghana side was more organic in nature, starting from the pre-colonial port used by European and African traders (Box 2.2). 


\section{Map 2.5}

The Lomé-Aflao cross-border agglomeration (Togo-Ghana)

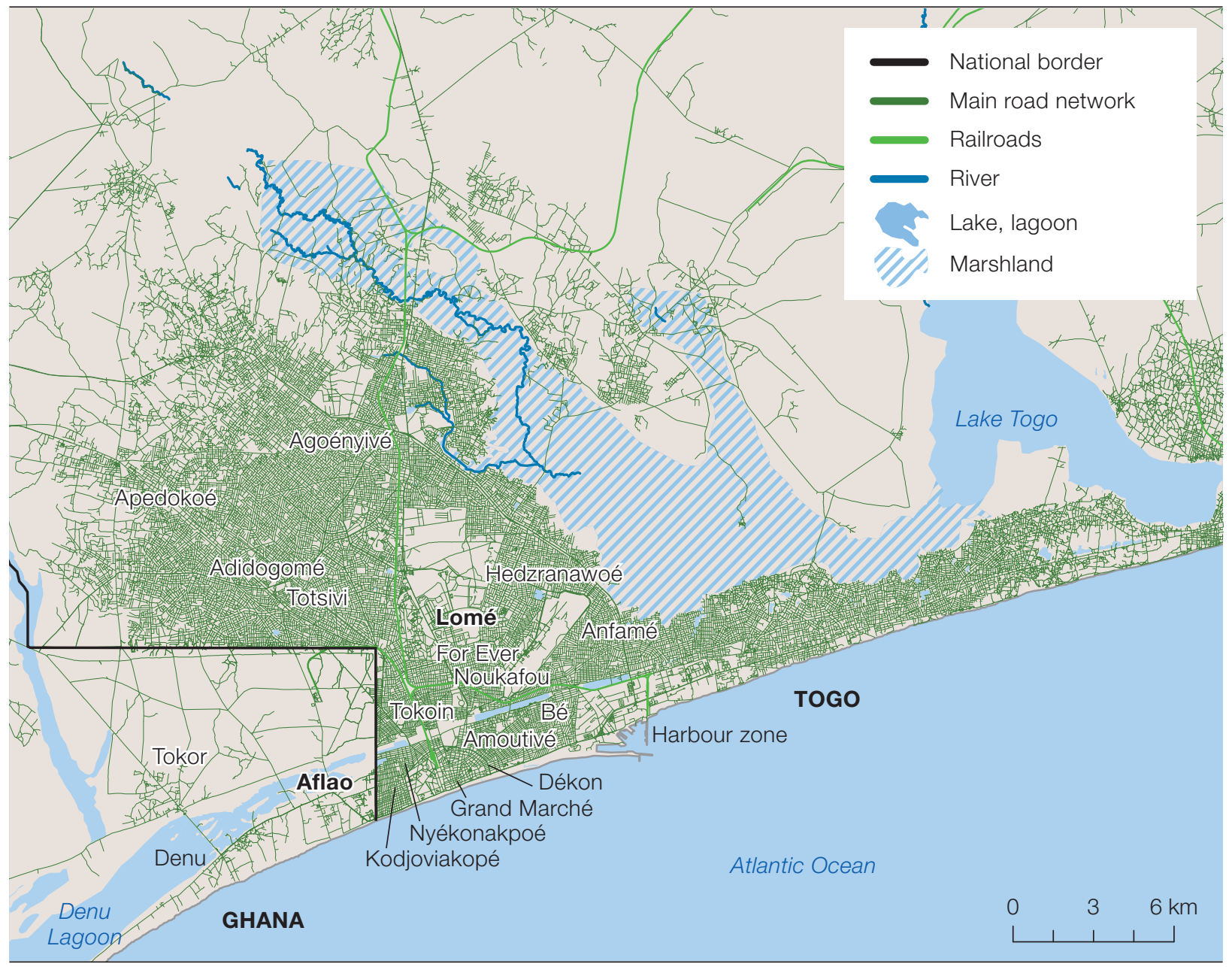

Source: OpenStreetMap 2018

\section{Box 2.2}

Lomé and Aflao: A special relationship

The Togolese capital of Lomé and the Ghanaian border town of Aflao are close in every sense. As passengers and vehicles from Aflao cross the border at Kodjoviakopé, they spill into the heart of the city. However, while they might appear to constitute a single settlement that has been partitioned, Lomé and Aflao have always been discrete entities. When the Gold Coast border was drawn at Aflao in 1874, a motley collection of traders seeking to avoid british customs duties moved just beyond the line to create a new community. Lomé only later became the German colonial capital. While there are numerous Aflao settlements that have been engulfed by the city as it has expanded northwards, the neighbouring quartier of Kodjoviakopé actually takes its name from its founder who hailed from Anecho in eastern Togo (Map 2.5).

It is commonly said that Lomé prospers at times of hardship in Ghana. The golden years were during the decade after 1975 when acute shortages in Ghana 
- gave rise to a lucrative contraband trade that brought good business to the port and to the trading community alike. Conversely, the current boom in Ghana has been associated with economic stagnation in the Togolese capital - exacerbated by ongoing political tensions. Evidently, Aflao has been shaped by its proximity to Lomé. This is reflected in the diversity of its population, which includes significant trading minorities from other parts of West Africa, of whom the Malians are the most numerous. Their presence is closely related to the influx of migrants into Lomé since 1990. Today, there is also a daily stream of buses carrying traders from Kumasi and Abidjan to the Aflao border. They typically walk into Kodjoviakopé and then take a vehicle to the Grand Marché before recruiting porters to carry the goods back into Aflao.

Aflao has also been shaped by its problematic relationship with the rest of Ghana where it has been considered as a troublesome periphery. The lack of attention to Aflao is reflected in the built environment, which did not see any great improvements during the years when trade with Lomé flourished. Today, there is one good single-track road that passes through Denu to the border - along which many new banks and filling stations are springing up - but the bulk of the roads in Aflao remain rough. Moreover, for all its commercial importance, and despite the fact that it was home to more than 84000 people in 2015, Aflao lacks a decent market. By contrast, Lomé has excellent roads and a large number of markets - as befits a city of 1.73 million people within its metropolitan area.

The juxtaposition of Lomé and Aflao raises a series of governance issues on which officials and border populations rarely see eye-to-eye. There are close familial connections between Aflao and particular quarters of Lomé, especially to the north of the city. Responding to the demand for easier passage, the two sets of authorities agreed to open the Beat 9 pedestrian portal that was designed specifically for local populations who would be subject to limited identification checks. However, after the initial success, there have been complaints about harassment and bribery by officials. The portal only operates for exceptional occasions because the Togolese authorities have closed off their section of border in the city. Nevertheless, there are numerous breaches that are exploited by smugglers. There are also estimated to be as many as 23 unofficial routes that are used by okada (motorbikes), ferrying passengers and contraband goods such as petroleum and textiles in either direction to the border.

The Ghanaian customs and immigration authorities have lobbied for the erection of a second border fence inside Ghana, but this would be deeply unpopular. Relations between the youth of Aflao and government agencies are already fraught, following a series of clashes in recent years over policing. Whereas police, customs and immigration services maintain that Aflao is a hotbed of crime that needs to be taken over, the paramount chief of Aflao has been amongst the vocal critics of existing controls, which he regards as unnecessarily intrusive.

The current drive towards regional integration has implications for both Lomé and Aflao. The Abidjan-Lagos Corridor, which is the priority project of the Economic Community of West African States (ECOWAS), currently passes through Aflao-Kodjoviakopé. The Togolese authorities are making improvements to the Autonomous Port of Lomé to render it more competitive with Tema and Cotonou where the wait times are considerably longer. The port itself lies at the eastern approaches to Lomé, which makes it conceivable to route the heavy goods traffic around the city centre, but trucks that are bound for Ghana currently have to go through the administrative heart of Lomé. Given that Kodjoviakopé is densely populated, there is almost no space for vehicles to park. In practice, this means that there is a buildup of trucks on the Ghana side as transporters seek to clear their goods at customs. The new border post built at Akanu/Noepé, some 40 kilometres from Aflao, hardly addresses this situation (see West African Papers, no. 23).

Source: Paul Nugent 2018 


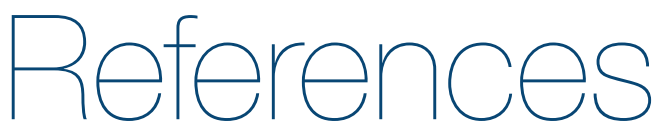

Allen, T. (2017), "The Cost of High Food Prices in West Africa”, West African Papers, No. 8, OECD Publishing, Paris, https://doi.org/10.1787/c2db143f-en.

Bach, D. (2016), Regionalism in Africa. Genealogies, Institutions and Trans-State Networks, Routledge, Abingdon.

Beuving, J. (2015), "American Cars in Cotonou: Culture in African Entrepreneurship and the Making of a Globalising Trade", The Journal of Modern African Studies, Vol. 53, No. 3, Cambridge University Press, pp. 317-338, https://doi.org/10.1017/S0022278X15000373.

Brooks, A. and D. Simon (2012), "Unravelling the Relationships between Used Clothing Imports and the Decline of African Clothing Industries", Development and Change, Vol. 43, No. 6, Wiley-Blackwell, pp.1265-1290, https://doi.org/10.1111/j.1467-7660.2012.01797.x.

Cantens, T. and G. Raballand (2017), "Cross-border trade, insecurity and the role of customs: Some lessons from six field studies in (post)conflict regions", ICTD Working Paper, No. 67, https://opendocs.ids.ac.uk/opendocs/bitstream/handle/123456789/13379/ICTD_WP67.pdf.

Coquery-Vidrovitch, C. (1993), Histoire des villes d'Afrique noire: Des origines à la colonisation, Albin Michel, Paris.

Dobler, G. (2016), "The green, the grey and the blue: A typology of cross-border trade in Africa", The Journal of Modern African Studies, Vol. 54, No. 1, pp. 145-169, https://doi.org/10.1017/S0022278X15000993.

Freund, B. (2007), The African City: A History, Cambridge University Press.

Gervais-Lambony, P. and G.K. Nyassogbo (eds.) (2007), Lomé: Dynamiques d'Une Ville Africaine, Karthala, Paris.

Glaeser E. (2011), Triumph of the City, Penguin Press, New York.

Golub S. (2012), "Government policies, smuggling, and the informal sector", in Benjamin N and A.A. Mbaye (eds.) The Informal Sector in Francophone Africa. Firm Size, Productivity, and Institutions, World Bank, Washington, DC. pp. 195-218.

Hoffmann, L.K. and P. Melly (2018), "Incentives and Constraints of Informal Trade Between Nigeria and its Neighbours", West African Papers, No. 16, OECD Publishing, Paris, https://doi.org/10.1787/7aa64379-en.

Howard, A.M. (2014), "Cross-Boundary Traders in the Era of High Imperialism: Changing Structures and Strategies in the Sierra Leone-Guinea Region", Articulo-Journal of Urban Research, No. 10, https://doi.org/10.4000/articulo.2535.

Koné, M.M. (2015), "Marchands ouest-africains et marchés frontaliers: construction d'une communauté d'affaires", Doctoral thesis, Université de Bordeaux, https://tel.archives-ouvertes.fr/tel-01399293/document.

Lamarque, H. (2014), "Fuelling the Borderland: Power and Petrol in Goma and Gisenyi", ArticuloJournal of Urban Research, No. 10, https://doi.org/10.4000/articulo.2540.

Locatelli, F. and P. Nugent (eds.) (2009), African Cities: Competing Claims on Urban Spaces, Brill, Leiden.

Lovejoy, P.E. (1986), Salt of the Desert Sun: A History of Salt Production and Trade in the Central Sudan. Cambridge University Press, Cambridge.

Miles, W. (1994), Hausaland Divided: Colonialism and Independence in Nigeria and Niger, Cornell University Press, Ithaca.

Myers, G. (2011), African cities: Alternative Visions of Urban Theory and Practice, Zed Books, London.

Niang, A. (2013), "The (In) Commodities of Laissez-faire Integration: Trade and Mobility in a Crossborder Market”, African Studies, Vol. 72, No. 1, pp.41-63, Routledge, https://doi.org/10.1080/0 0020184.2013.776197.

Njoh, A.J. (2006), "African cities and regional trade in historical perspective: Implications for contemporary globalization trends", Cities, Vol. 23, No. 1, pp.18-29, Elsevier, https://doi. org/10.1016/j.cities.2005.07.009.

Nugent, P. (2002), Smugglers, Secessionists \& Loyal Citizens on the Ghana-Toga Frontier: The Life of the Borderlands Since 1914, James Currey Publishers, Oxford.

Nugent P. (2012), "Border Towns in Comparative Perspective", in Wilson T.M. And H. Donnan (eds.), A Companion to Border Studies, Wiley-Blackwell, Chichester, pp. 556-572. 
OECD/SWAC (2019), Africapolis: Urbanisation dynamics in Africa, West African Studies, OECD Publishing, Paris (forthcoming).

OECD/SWAC (2018), Africapolis (database), www.africapolis.org.

OECD/SWAC (2017), Cross-border Co-operation and Policy Networks in West Africa, West African Studies, OECD Publishing, Paris, https://doi.org/10.1787/2074353x.

OECD/SWAC (2014), An Atlas of the Sahara-Sahel: Geography, economics and security, West African Studies, OECD Publishing, Paris, https://doi.org/10.1787/2074353x.

Onuzo, C. (2018), Welcome to Lagos, Faber \& Faber.

OpenStreetMap (2018), Benin, Ghana, Niger, Nigeria and Togo, https://download.geofabrik.de/africa.html.

Soi, I. and P. Nugent (2017), "Peripheral Urbanism in Africa: Border Towns and Twin Towns in Africa", Journal of Borderlands Studies, Vol. 32, No. 4, pp. 535-556, https://doi.org/10.1080/08865655.2016.1196601.

Sougué, E. (2016), "Malanville-Gaya, une dynamique de territorialisation à la frontière BeninNiger", Territoire en mouvement, Vol. 29, https://doi.org/10.4000/tem.3216.

Storper, M. and A.J. Venables (2004), "Buzz: Face-to-face contact and the urban economy", Journal of Economic Geography, Vol. 4, No. 4, pp.351-370, Oxford University Press, https://doi.org/10.1093/jnlecg/lbh027.

Titeca, K. (2012), "Tycoons and contraband: Informal cross-border trade in West Nile, northwestern Uganda", Journal of Eastern African Studies, Vol. 6, No. 1, pp.47-63, Routledge, https://doi.org/10.1080/17531055.2012.664703

Van der Haak B. (2005), "Lagos Wide \& Close. An Interactive Journey into an Exploding City", Amsterdam, Submarine, http://lagos.submarinechannel.com

Walther O. (2015), "Business, Brokers and Borders: The Structure of West African Trade Networks", Journal of Development Studies, Vol. 51, No. 5, pp. 603-620, https://doi.org/10.1080/00220388.2015.1010152.

Walther O. (2014a), "Trade networks in West Africa: A social network approach", Journal of Modern African Studies 52(2): 179-203.

Walther, O. (2014b), "Border markets: An introduction", Articulo-Journal of Urban Research, No. 10, https://doi.org/10.4000/articulo.2532.

Walther O. (2012), "Traders, agricultural entrepreneurs and the development of cross-border regions in West Africa", Entrepreneurship and Regional Development, Vol. 24, No. 3-4, pp. 123-141, https://doi.org/10.1080/08985626.2012.670909.

Walther O. (2009), "A mobile idea of space. Traders, patrons and the cross-border economy in Sahelian Africa", Journal of Borderlands Studies, Vol. 24, No. 1, pp. 34-46.

World Bank (2009), World Development Report 2009: Reshaping Economic Geography, World Bank, Washington, DC

Zeller, W (2015), "What Makes Borders Real - In the Namibia-Zambia and Uganda-South Sudan Borderlands", Unigrafia, Helsinki, http://urn.fi/URN:ISBN:978-952-10-9155-1. 



\section{West African Papers}

\section{Population and Morphology of Border Cities}

This report, part of the "Cities" collection, provides an analysis of the demographic and morphological changes in West African border cities since the mid-20th century. Using the Africapolis harmonised database makes it possible to show that since 1950 border cities have experienced higher rates of growth than other cities in the region. While the average size of cities increases with distance from a border, the opposite is true for urban density; it decreases as distance from a border increases. This suggests that border cities form urban centres that differ from other such centres due to the fact that they specialise in the commercial activities that stimulate growth and foster higher densities. The report identifies the 27 main cross-border agglomerations in the region and discusses their specific characteristics. 